\title{
$m$
}

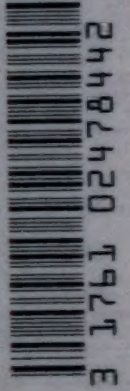


Digitized by the Internet Archive in 2007 with funding from Microsoft Corporation 



\section{THE CULTIVATION OF OSIERS AND WILLOWS}





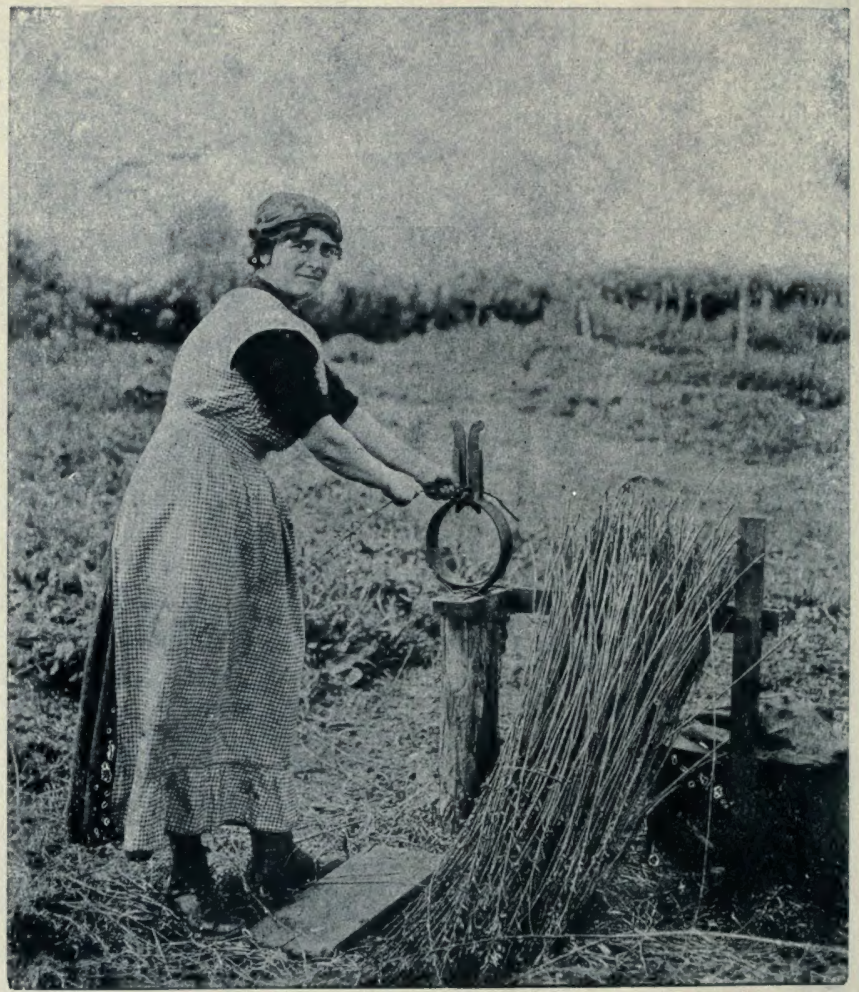

PEELING FOR WHITE.

Frontispiece 


\section{THE CULTIVATION OF \\ OSIERS_AND WILLOWS \\ BY \\ WM. PAULGRAVE ELLMORE}

EDITED, WTTH INTRODUCTION, BY

THOMAS OKEY

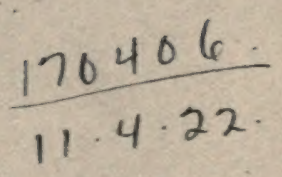

MCMXIX

LONDON AND TORONTO

J. M. DENT \& SONS, LTD.

PARIS: J. M. DENT \& FILS 
All rights reserved.

$$
\begin{aligned}
& S D \\
& 397 \\
& 082 E 5
\end{aligned}
$$




\section{ERRATLM.}

Introduction, p. vii. For "monœcious" read "dicecious." The male and female flowers are on different plants. 



\section{INTRODUCTION}

THE basis of this work originally appeared in the pages of the Journal of the Board of Agriculture during the years I9II and I9I2 over the signatures of Mr. W. P. Ellmore and the present writer. Revised by Mr. Ellmore, the articles were published in I9I3 by the Board of Agriculture and Fisheries in the form of a pamphlet which is out of print. With the permission of the Board, and further revised and amplified by Mr. Ellmore, they are now issued in book form to the public at a price which it is hoped will ensure their wide and careful consideration and result in their practical application.

The Board of Agriculture and Fisheries have, of course, no responsibility whatever for this book as now issued.

Mr. Ellmore's thanks are due to the Board for permission to reprint from the Journal of the Board of Agriculture a chapter on "Insect Pests " which appeared in the issue of November I9I7, and for the loan of the blocks of the photographs illustrating this volume.

The treatise on willow (or osier) cultivation here offered to the public is the first attempt in English to deal in a compendious and practical manner with a much-neglected branch of agriculture. Among other deficiencies in home supplies of raw material which the war has revealed, that of willows for basket-making purposes has been patent. The output of certain war material and the harvesting and marketing of farm 
produce have been seriously imperilled owing to the failure of imports from the Continent and elsewhere on which basket-makers and willow-workers have hitherto relied for half their consumption. This defect in the national resources is the more to be deplored in that no country in the world is better adapted for the cultivation of commercial willows than our own; and no crop, granting intelligent and skilful treatment, affords a more profitable return to the grower. Indeed, the elder Pliny in his Historia Naturalis (1. xvi, c. 69) remarks that Cato held an osier bed in higher estimation than an olive plantation or than wheat or meadow land.

The writer of the present Introduction is able to assure those concerned, from half a century's practical experience as a basket-maker and dealer in willows, that the responsible author of the ensuing treatise, Mr. W. P. Ellmore of Leicester, is second to none in this country in possessing the expert knowledge and matured judgment necessary to warrant the publication of a work of this nature-knowledge and judgment based not only on English methods, but on those adopted by continental growers in Belgium, Holland, France and Germany.

A relevant word which the present writer alone is responsible for may not be inopportune. From time immemorial commercial willows have been exclusively propagated from cuttings, and the curious may learn from Columella's De re Rustica (1. iv, c. 30) that the methods employed in ancient Roman times for the propagation and cultivation of osiers are substantially those described in the present treatise. So enfeebled, therefore, have the stocks become by artificial methods of reproduction that the rods fall an easy prey to 
insect and fungoid pests. ${ }^{1}$ In a letter to the Board of Agriculture (October I8, I9I8) Mr. Ellmore stated: "I have just recently spent most of a fortnight in looking round crops in this (Leicestershire) and other districts, and I have never seen such general destruction before, arising from grubs of various kinds and beetles. Varieties that have never been known to be attacked have suffered considerably this last season." The willow in its natural state, as a monocious plant, is reproduced by cross fertilisation. Under such conditions it attains great vigour of growth, and its range of distribution reaches to the line of perpetual snow. An effective method, therefore, of combating destructive agencies, especially diseases of a fungoid nature, would be to renew and fortify stocks by cross fertilisation, and thus increase their disease- and pestresisting power. Experiments in this direction have already been made by a leading authority on the order of Salices, the Rev. E. F. Linton, who between I89I and I897 was able artificially to hybridise certain species, and who believes that under suitable conditions he could raise improved osiers by cross fertilisation. The present writer drew attention to this aspect of willow cultivation during Mr. Walter Runciman's tenure of office, who expressed his great interest in the suggested improvement of osier stocks by cross fertilisation, and quite agreed in its possibility as a profitable subject for research. The Minister also wrote that he would see what he could do to bring it before the notice of agricultural scientists. Nothing since has been heard of the matter.

\section{THOMAS OKEY.}

1 A leaflet entitled "Insect and Fungus Pests of Osiers and Villows" is about to be issued by the Board of Agriculture and Fisheries. 



\section{CONTENTS}

INTRODUCTION

\section{CHAPTER I}

The Cultivation of Basket Willows .

Soil and Situation-Preparation of Grass and Arable LandGrubbing up Old Beds-Drainage-Supply of LabourPlanting - Cultivation or Cleaning-Manuring-HarvestingCutting the Maiden Crop-Tying into Bundles and Carting - Summary of Directions to Willow Caltivators.

\section{CHAPTER II}

\section{Expenses AND Returns}

Cost of Cultivation and Yield-Cost of Cutting the Crop and Carrying Off.

\section{CHAPTER III}

VARIETIES OF WILLOWS

\section{CHAPTER IV}

\section{Preparation and Marketing}

Preparation of the Rods-White Rods-Preparation for Whitening-Couching-Pieing-Pitting-Peeling for WhiteBreaks-Drying White Rods-Buffing-Suitable VarietiesTime of Cutting-Boiling-Tanks for Boiling-Peeling Buft by Haind and by Breaks-Drying for Buff-Grading and Tying into Bundles-Brown and how to Preserve it.

\section{CHAPTER V}

Insect Pests of Basket Willows .

Damage to Leaves and Terminal Buds-Damage to RodsDamage to Stumps-Insect Pests: Willow Aphides-Willow Beetles - Willow Sawfies - Willow Moths - Willow Gall Midges-Methods of Control.

\section{CHAPTER VI}

\section{TREE WiLlows
Salix carulea or Blue Willow-Salix fragitis
CHAlix alba or White Willow-Salix caru
CHAPER VII}

IMPORTS AND EXPORTS .

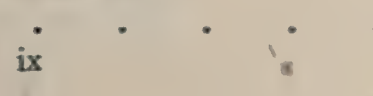




\section{LIST OF ILLUSTRATIONS}

Peeling for White '. . . . Frontispiece

I. Planting Chain

2. Grubber . . . . . . . . 8

3. Hooks Suitable for Cutting Willows . I

4. Rods in the Couch . . . . . 54

5. Machines for Peiling Willow Rods • . 56

6. BRAKes " " " " . . 56

7. White Rods out to DRy . . . 69

8. Grading Willows into Different Lengths . 69

9. MAchine for Tying Willow Rods For Export 72

ro. Steel Peg and Chain for Tightening the BUNDLE • . . . . . . 72

II. Machine for Tying Willow Rods . • 73

I2. $\quad$ "

13. A Willow Tree . . . . . . 88 


\section{OSIERS AND WILLOWS}

\section{CHAPTER I}

THE CLLTIVATION OF BASKET WILLOWS

THE term "basket willows" defines those species of plants of the genus Salix which are grown for the making of basket-ware.

Growers, merchants, and makers divide basket willows into two main groups, viz.; (I) Hard rods, and (2) Soft rods. While these terms are used in a relative sense only, they indicate the main difference existing between the two classes. The "hardness" of a rod depends upon the proportion of wood to the pith in any given rod, as well as upon the closeness in the texture of the wood itself. "Hardness," therefore, in the sense that it is used by the basket-makers, is determined by the working qualities of the rod for basket-making. Hard rods belong to the species $S$. triandra and $S$. amygdalina. The soft varieties belong to the species viminalis and are more open grained in the wood. They contain more pith, and as the rods possess working qualities somewhat inferior to the hard rods described above they are termed "Soft Rods " by the willow-workers.

Rods of the species $S$. viminalis have a very full top, and hence they are known in some districts as "full 
tops." Rods of $S$. purpurea and most of the varieties of S. triandra and S. amygdalina are more pointed, hence the name of "fine tops." The rods of the $S$. purpurea and alba have both a fine top, but not so fine as the triandra. In some districts the term " osier" is applied to all rods of the viminalis class, the rest being called "willows," but both these terms are used quite loosely and irrespective of species.

In making a selection of varieties for planting, a grower naturally wishes to choose those sorts that will ultimately yield him the best return financially. Owing to continental competition the market gardeners' basket-making industry has in late years undergone changes, the tendency being for English workers to produce high-class goods and to leave the making of a large quantity of the cheaper baskets to other countries. It is, therefore, difficult to find a market for rods which are badly grown or of poor quality, but rods of better quality when peeled and prepared as "white" or "buff," are in more demand than hitherto.

Growers should certainly plant more than one sort to meet variations in season, which may suit one kind better than another; but it seems almost essential that the larger proportion planted should consist of varieties suitable for " white" or " buff" rods. Soft rods being vigorous growers are suitable for producing large sticks, which are much required by all makers of basket furniture and transit hampers.

A basket-maker having willow grounds naturally grows those sorts which are the most suitable for his business, and in cases where a constant local demand for a certain class of rod exists, it is generally good policy on the part of the grower to cater for it, provided the soil of his district is suitable. 


\section{SoIl AND Situation}

Basket willows are to be found growing in river valleys in all parts of the United Kingdom, but the most extensive beds are found in the valleys of the rivers Thames, Parret, Kennet, Great Ouse, Cam, Soar, Trent, Stow and Welland.

Willows of one kind or another will do reasonably well on most soils, and where there is a loam of from 6 to 8 in., with a stiff marl or clay subsoil, there need be little doubt as to the results being satisfactory. Ideal land for willows should allow of irrigation during dry summers. During the months of May to August almost every one of the best fine-top kinds will do better if aided in this way.

In order to meet this condition I have employed near Loughborough a Hornsby 4 h.p. oil engine, mounted on a concrete bed, standing $6 \mathrm{ft}$. above the level of the land; together with a centrifugal pump capable of pumping from a well at the rate of 20,000 gallons per hour. The water was for the purposes of this bed distributed by double-armed delivery pipes to portable troughs- $15 \mathrm{ft}$. long by 7 in. wide and $6 \frac{1}{2}$ in. deep; the bottoms being $\frac{3}{4}$ in. thick and the sides $\frac{5}{8}$ in. These troughs were connected by an additional piece of wood secured under the bottom, and two pieces forming flaps at the sides. They were extended to the highest point of the land upon temporary " horses," consisting of two supports made from 2 in. willow poles driven into the ground, and a traverse piece across the top, graduated with sufficient fall to carry the water to the furthest point, where the main discharge is made. Fine-top rods aided in this way maintain a constant healthy growth. 
It is necessary that the ground should be well drained to avoid the injury to the crop which would arise from excess of wet during the winter months. The life of the heads, the quality of material, and the yield are very materially affected by wet and cold. $S$. triandra and $S$. purpurea will do best under damp and moderately heavy soil conditions. Other varieties, chiefly those of the S. viminalis species (the true osier) will thrive under much drier conditions. ${ }^{1}$

It should be clearly understood that willows of commercial value will not grow on wet, undrained, swampy or peaty ground.

At the same time the situation of the willow holt should be such that the long spreading rootlets of the plant can draw upon abundance of moisture at all times. These conditions can best be fulfilled by lowlying land in the neighbourhood of rivers or watercourses. The water-course provides a cheap and easy means of carriage from the holt to the preparing yards.

\section{Preparation of Grass and Arable Land}

As a rule arable land is not equal to meadow, because it usually lacks that high state of fertility which follows the breaking up of old turf. Even in the case of old turf it is found that the willow crop greatly benefits by the headlands having a good, heavy dressing of manure ploughed in. No willow crops grow so well on the outside as on the sheltered, inside portion; consequently the extra stimulus to the poorer fringe-which is exhausted by tree and hedge growth-will bring the

1 The types of soil best suited to the different varieties are discussed in the section on "Varieties of Willows." 


\section{THE CULTIVATION OF BASKET WILLOWS 5}

outside more into character with the rest of the field. It is sometimes stated that willow growing impoverishes the land, but this is not the case, as may be judged from the following example:-

Some twenty-five years ago 40 acres of good, heavy, arable land at Thurmaston, near Leicester, were taken by a grower for willow cultivation, and after being fallowed for one summer to clean it from twitch, etc., about 60 loads of well-rotted farmyard manure to the acre were applied before ploughing 12 in. deep. The land was planted in the following spring with satisfactory results. It was cropped for fifteen years, when it was taken over and cultivated by a successor, who, during 1909 and I9I0, grubbed it up and turned it again into corn land. In the autumn of I9II it yielded eight quarters of excellent marketable wheat to the acre, and was sown again with wheat the following season, producing seven quarters to the acre.

Instead of willow growing impoverishing land, the heavy foliage which falls each autumn materially enriches it, especially if the leaves are turned under the soil for some 2 or $3 \mathrm{in}$. in the wake of the cutters.

Of the recognised ways of breaking up grass land, double digging unquestionably produces the best results. That method, however, although showing by far the best after-returns, is a very expensive one, and is only recommended where the area is small, or where the land is unsuitable for the plough.

A strong and specially made plough may be employed, fitted with a revolving cutting knife in front of the coulter to cut the grass about 3 in. deep, followed by a skimmer about 5 in. wide, and fitted with a 24 -in. wheel for the furrow. The breast-plate of this plough 
should be much longer and have more throw-over than that of the ordinary plough, to enable it to turn over the ridge or seam and lay it as flat as possible, and plough the soil not less than 9 in. deep. This process gives the young roots a better chance of penetrating the deeper soil. The cost of this method works out, including the after-harrowing, at $£ 34$ s. per acre; it needs six horses and a more than usually strong ploughman, owing to the great depth to be turned up and to the exceptional strength required to handle and turn round such a heavy plough. It is only recommended where there are no specially undesirable weeds in the land.

If weeds such as burnet, docks, reed grass, pilewort, and meadow-sweet are present, a double course of ploughing to break up the land is very desirable. An ordinary plough with two horses should go first and take off about 3 in. of turf. This should be followed by the stronger plough with six stout horses, as described above, in order to break up the subsoil to a further depth of 9 in. This system, which, together with the harrowing, costs about $£ 3$ I8s. per acre (prewar price), enables the turf to be laid flat at the bottom of the furrow, and as the head of the burnet is shielded in the turf, it is largely killed. This weed is difficult to eradicate, and if odd patches of it appear again the following summer, the most effectual treatment is to have the patches forked out. Hoeing tends to propagate rather than kill, and if the men employed use reasonable care the roots of the willows will not be damaged by the forking process.

In preparing for osiers at Loughborough in Igro it was found that the use of a steam cultivator was the most efficacious way of getting rid of large masses of 
burnet. The field was dragged both ways to a depth of about 4 in.; then the land was left exposed to the sun for several weeks, and the same double operation repeated for the purpose of further breaking up the turf. After five weeks' longer exposure the process was repeated, the drag going twice over the ground on each occasion. The last operation completely broke up the whole of the turf, the root portion of the burnet by this time being withered, although quite alive where embedded in the turf; thus the head part of the plant was exposed to the action of the sun in the months of September and October, and all growth destroyed. The land was then ploughed to an inclusive depth of Io in., six horses being engaged for this work. Left thus until the first week of the following February, the ground was found to be in excellent workable condition, and was accordingly harrowed over twice; the soil, being broken down like an ordinary garden soil, was ready for planting at the end of the month.

\section{Grubbing up Old Beds}

In cases where an old willow bed is to be replanted the presence of the old stumps prevents the use of the plough, and the usual practice is to dig up the stumps during the autumn and winter months, at the time the land is being trenched or dug. The old stumps are collected in heaps, and, when dry, they are burnt and the ashes scattered over the land. This entails much labour and is necessarily costly, the prices paid varying considerably up to 2 . per perch, according to the scale of wages in the district, the nature of the soil to be dug, and the number of heads to be pulled up. 
I use for grubbing purposes a tool specially designed to lever the old stumps out of the ground (see illustration, Fig. 2). The tool should be of much use to willow growers in the future, as it will enable the work to be done quicker and at less expense, since, when the old stumps have been cleared, the land may be ploughed as indicated above.

In Berkshire and East Anglia the beds are replanted with sets in the following spring, and in both districts there are many fields that have been cropped with willows continuously for over a hundred years. The practice, however, is not advisable in all districts, and in Somerset the growers prefer to give their land a short change before replanting. There, the land which has been cleared of the old stumps and dug over is left fallow for a summer; in the autumn it is ploughed up into ridges and replanted with sets during the following spring. Quite recently a few of the growers in that district have grown one crop of wheat on the land before replanting it to willows-a practice to be commended at the present time.

Unfortunately the fertile land usually found in the willow districts abounds with weeds of various kinds, and an energetic effort must be made to clean the land by harrowing and dragging it in the spring. In cases where the weeds are very numerous and troublesome, it may be necessary to summer fallow the land, to clean it thoroughly for planting during the following spring. It is highly important that such weeds as dock, rushes, reeds, grasses, pilewort, meadow-sweet, convolvulus, and burnet be cleared off, as they seriously interfere with the growth of willows. Such weeds are difficult to eradicate by cutting when once the willows have been planted. 


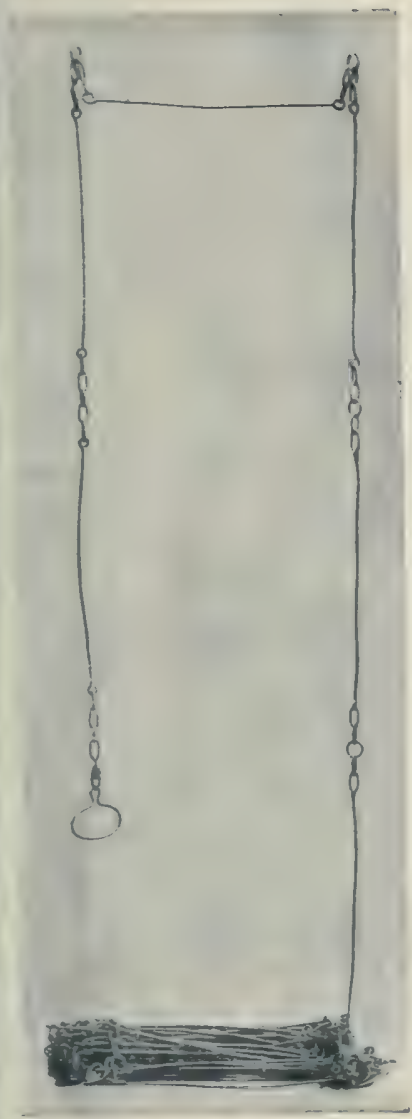

Fig. 1. - A Plasting Chais, Which is provided with rings at intervals of every 20 in. At this ring the set or cutting is pushed into the ground.

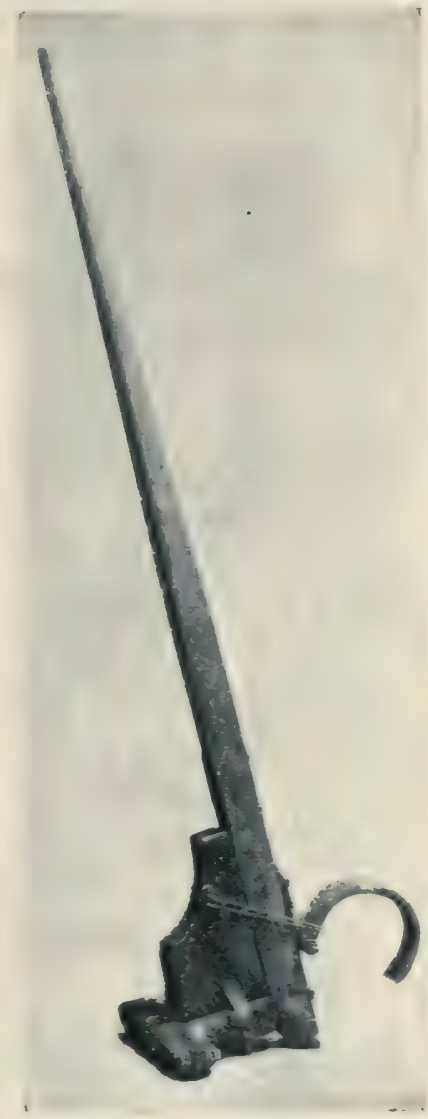

FIG. 2. - "GRUBBER,"

Or tool used for pulling old stnols from the land when the holt is being grubbed up.

To face page 8 . 



\section{THE CULTIVATION OF BASKET WILLOWS 9}

Whatever system is adopted, the aim should be to cultivate the soil to a depth of 9 or $10 \mathrm{in}$. so as to reduce it to a loose, friable condition, free from any troublesome weeds.

\section{DRAINAGE}

Sufficient attention is seldom paid to the question of drainage. Before planting willows on fresh land it is important that a proper system of drainage should be devised and carried out. If this is done, frequent and heavy floodings will not be harmful to the willows. Surface drainage must be accomplished by means of trenches or grips, and pipe drainage is absolutely useless because in a few years the pipes become choked with root growths. The number and size of trenches required will be determined by the character of the land, and the quantity of water to be removed.

Sewage farms are usually thrown up into beds with open grips on each side. Although willows grown on this system have in most instances proved a complete failure, this is entirely owing to the unsuitable varieties which have been planted. The variety $S$. hippophaifolia is the only species suitable for this intensive system of culture. It has stood the têst of time and yields a quality equal to many rods produced under ordinary conditions. For all work where a full top is desirable it is probably unequalled, and will make excellent white, buff or brown.

\section{SUPPLy OF LABOUR}

It is inadvisable to attempt willow growing extensively where there is any scarcity of labour. No 
branch of agriculture needs so much expenditure for labour per acre as that of willow growing if the ground is efficiently cultivated, and the produce properly sorted, graded, peeled, and prepared.

In many districts of England willows are in considerable demand unpeeled, either green or brown, $i$.e. dried. The difficulty of obtaining an abundant supply of labour is in these districts surmounted by cutting the crops in the winter-usually from December to March-when work is slack. But conditions are considerably altered when the willows are to be peeled for buff, an operation which is generally carried on by women in the winter months, or for white, in the months of May, June, and July, just at the time when labour is in demand.

\section{Planting}

Land trenched or ploughed in the autumn will be ready for planting as soon as it has settled down into a firm bed. This will usually be about the end of February or during March, but, if the land was prepared before the autumn, the sets may be planted any time between November and March.

The general method of planting is to use an Italian hemp cord of three-ply with strips of linen passed between the strands of the cord at regular intervals as indicators for the sets, the distances at which the strips are placed being determined by the variety being planted. (For distances of the different varieties see particulars given under the heading "Varieties of Willows.") This method often throws the sets out of their true distances, because in the length recommended (40 yds.) the cord varies according to the 
dryness or humidity of the atmosphere. This method, however, will probably be found as useful as any other in the case of a small area.

A still less expensive way is to use any kind of cord as a guide for the straight lines and to cut a stick equal in length to the distances between the plants, and using that as a guide for planting.

To overcome the difficulty created by a shortening or lengthening of the cord, a planting chain may be used, somewhat similar to those employed by land surveyors, with I-in. rings inserted at equal distances as guides for the planter. Every third link should be fitted with a swivel, to prevent the twisting or kinking of the chain (see illustration, Fig. I).

It is customary for willow growers, alike in. Great Britain, France, Belgium, Germany, and Holland, to plant closer in the rows than between the rows. Planting in squares, $i . e$. at equal distances between heads and rows, but varying according to the natural growth of each particular variety, has, however, decided advantages. "Square planting" enables the cleaning for the first few years to be done by the horse-hoe in both directions. The proper ripening and hardening of the wood also is dependent on the action of the sun, and this system gives sunlight free access to the head in the growing period. It also stimulates even growth, since the roots have an equal quantity of soil all round from which to draw" food.

Either one- or two-year-old sets may be used for propagation purposes, but unquestionably two-yearolds are the best. Some growers prefer the one-yearold, believing that they throw off more shoots the first season than two-year-old sets. This belief may have some foundation, especially if the two-year-old sets 
are cut from the butts of a badly grown two-year-old crop, as they often are in the case of inexperienced or careless growers. The practice recommended, however, is to leave the best-grown and healthiest one-yearold rods for two years' growth.

From such rods six or seven sets can be cut, and it is obvious that healthy plants will give a better crop than cuttings from dwarfed or badly grown rods. When, however, only two or three sets are taken from the rod-and this is a very common practice-the argument for the younger or one-year-old rod holds good.

The third and higher sets cut from a two-year-old plant throw out more shoots than the sets cut close to the butt end, where the wood is harder and the eyes are consequently less active, but, on the other hand, there is always a great risk in using one-year-old sets, owing to their being thinner and less hardy. With dry winds and an absence of showers in the months of April and May one year-old sets will very often die or sicken, whilst two-year-old sets, being much stouter and their bark far thicker, will withstand the dry time more successfully.

Twelve inches is the best length to cut the sets. They must be cut on the slant for inserting in the ground; but the end which is to remain out of the ground should be cut nearly straight and just above an eye. With this extra care very few sets will show any dead wood, and a nicely-shaped head will be the result. The cutting of the sets must be performed with a sharp knife, in order not to bruise the bark or wood. They must be buried so that about I in. is left exposed above the surface, and the eyes must always point upwards. The land, being freshly 
broken up, will subside a little during the summer, leaving the head about 2 in. out of the ground. If the sets are cut longer the extra length is wasted, because the roots seldom strike more than Io in. below the surface, whilst if the sets are left higher out of the ground the crop-after the close of the growing season -will be needlessly exposed to the winter winds, which may sway the heads to such an extent as to loosen them and indirectly kill them by the admission of frost and water. Particularly is this the case with the first, or maiden, crop, on account of the small root growth. The closer the head or stool is to the ground, the less it suffers from storms. Many French growers are accustomed to plant sets at an angle of $45^{\circ}$ on the supposition that they thus root more freely. This is believed to be an error, and is now being discarded in favour of vertical planting.

Sets can be purchased from most willow growers at prices ranging from $I_{5} s$. to $£ I$ per Iooo sets, including packing for travelling. The price varies with the variety of willow, and the age of the sets required. Those from two-year-old rods always realise a higher price than those cut from one-yearolds.

When buying it is indispensable that every set should be true to its kind, so as to produce an even and true crop. This point cannot be sufficiently emphasised. The growing of a mixed crop of willows is to be guarded against as the taller varieties would overshadow the shorter varieties and the coarser and more robust growers would crowd out the slower growing varieties. The mixed crop, too, when cut would be troublesome to peel as the dissimilar rods would attain their best peeling period at different times. 
Having regard to the importance of sets being supplied from healthy cuttings, a guarantee should be obtained from the supplier, who, if he is a man that understands his business, will have no hesitation in giving it, that the cuttings are true to their respective names or kinds, and cut from rods which were not in the previous season attacked by aphis or any disease.

Growers should always plant more than one sort to meet variations in seasons, which may suit one kind better than another. It is indispensable that every species or variety be planted true to its kind. This point cannot be sufficiently emphasised, because different kinds produce marked contrasts in quality, even when the treatment is identical, and when this is the case the market for high-class manufactured goods is either lost or a much lower price realised. Nothing from the standpoint of the skilled worker is worse than to see several sorts of material in his product. By planting several sorts the requirements of an allround trade will be met, and the longest time possible be gained for harvesting the crop. Between the sap rising in the earliest and the latest sorts there is sometimes a period of three weeks.

\section{Cultivation or Cleaning}

After the ground is planted it is most essential that all weeds should be kept down by hoeing. Weeds, if allowed to spread, not only affect the growth of the willows, but also the quality of the material. Especially is this the case with the finest and choicest kinds of willows when one year old. Any saving effected 
by sparing the hoe is more than lost when the crop is to be used for white or buff peeling, because the grasses have then to be sorted out by hand-a tedious and cold operation at that period and involving tying up twice. The net result would be a saving of $\delta^{I}$ in the summer, and an expenditure of $£^{I} 5 \mathrm{~s}$. in the winter.

In the case of maiden crops, hoeing right up to August I is resorted to, in order to maintain the surface of the soil in a loose condition. If this is allowed to bake or crack, many heads will be found dead the following spring, and the grower will be fortunate if failure to keep the top soil open does not render the crop subject) to disease. It should be remembered that a heavy strain is imposed on the plants, which are endeavouring to develop simultaneously a shoot growth above ground, and a root growth below. For lack of sufficient hoeing during the first year many acres may be destroyed by green fly and honey dew, especially if the spring proves to be a dry one; and this not only results in a year's loss of growth, but also necessitates planting again the following season. In the case of older heads the hoeing ought not to be discontinued so long as the men can move freely in the crop, generally up to the middle of June. By that time the willows begin to make such rapid growth that they smother all the undergrowth, and only in the outside rows will any further attention be required.

Several methods are adopted for keeping the land clean. One found most suitable in Leicestershire is the employment of a three-tined horse-hoe with an arrow-head shaped blade on the front and two L-shaped blades behind. This can only be used if great care is 
exercised to prevent barking the head by striking it with the hoe, thereby occasioning considerable exhaustion of the plant, and consequently a defective crop. Moreover, this hoe can only be brought into play for the first year or two, whilst the heads are sufficiently small, and the spaces allow a pony or small horse to travel between the rows. A swannecked hoe will usually be found the best tool for this purpose.

For the purpose of filling up a bed in after years, it is a good plan to allocate a small portion of the ground devoted to each variety for transplanting purposes. When necessary take up an entire plant, cutting off all the rods except two of the best grown ones, and nicely and cleanly cutting back the roots; place this in the space from which you have taken a dead head and leave it to grow for two years, after which you may cut it down, and by this means keep your ground in a thoroughly healthy planted-up condition.

In Lancashire where the variety Dicky Meadows is extensively grown a unique method of cultivation is practised. In the early spring a double-breasted ridging plough is run down the centre of the rows one way; this breaks up the soil and banks it near the heads of the plants, which are in this district planted from 9 in. to Io in. apart and $2 I$ in. between the rows. After the soil has assumed a nice crumbly condition, a scuffler is run down between the rows, thus clearing the soil from the heads and levelling the whole.

The Board of Agriculture issue a leaflet (No. II2) which contains useful advice on the suppression of weeds. 


\section{MANURING}

Many of the willow holts are flooded during the winter months, and the thick sediment left contains valuable plant food. In such instances no other dressing is required. It is a good plan to give poor holts a top dressing with farmyard manure, by the aid of which the yield is said to be increased. Mr. Hutchinson, of the Midland Agricultural College, found that a dressing of sulphate of ammonia increased the length of the rods grown, but states that the result of applying superphosphate ( 36 per cent. soluble) at the rate of $5 \mathrm{cwt}$. per acre, sulphate of potash at the rate of 3 cwt. per acre, and sulphate of ammonia at the rate of $I \frac{1}{2}$ cwt. per acre, together at four different centres, showed that the plots had received advantage from the treatment, but the increased crop did not pay for the cost of the manures.

It has been found that lime considerably sweetens and fertilises soils having a sluggish drainage and a tendency to grow moss, but lime may not be suitable to all classes of soil and all situations. The practical agriculturist will determine for himself whether its application is suitable or otherwise. It may be of considerable interest to growers to know that willow peelings, up to now regarded as a by-product of no value, form excellent manure for potato growing and other purposes. It was demonstrated in 1906 by Messrs. Sutton \& Sons on their experimental grounds at Reading, that this manure, used at the rate of 30 tons per acre, produced a heavier crop than farmyard manure at the same rate. The peelings are allowed to lie on the ground and rot for twelve months 
or more before use. Peelings have also been used with success for cucumbers and vegetable marrows, and celery grown by the aid of willow peelings always obtained first prize at a Midland Counties show. The peelings, when ground down into a fine powder, are found to be a fine fertiliser for many kinds of plants.

\section{HARVESTING}

The termination of the growth and the ripening of the wood will be determined better by the fall of the leaf than by the calendar. This stage varies in England from the end of October to the middle of November. When the leaf has nearly all fallen the rods are ready for cutting, but it is not advisable to commence cutting at this early period except for the purpose of buffing, which operation should be begun on the earliest possible date, in order to take full advantage of the short mild season before Christmas.

It will be found profitable to leave a portion of the one-year-old crop standing for two-year-olds. This undoubtedly gives the heads a rest, and the succeeding crop of one-year-olds will be found taller and heavier than that from the heads which have been cut each year. This practice might be carried out about every fifth or sixth year. Another good practice is to cut out with a sharp knife or fine shears all the smaller or rough growths. This will amply repay the grower for the labour expended, for, if left on the heads, these worthless growths will draw a certain amount of vitality from the head, and ultimately get smothered by the more vigorous rods, and need to be sorted out 



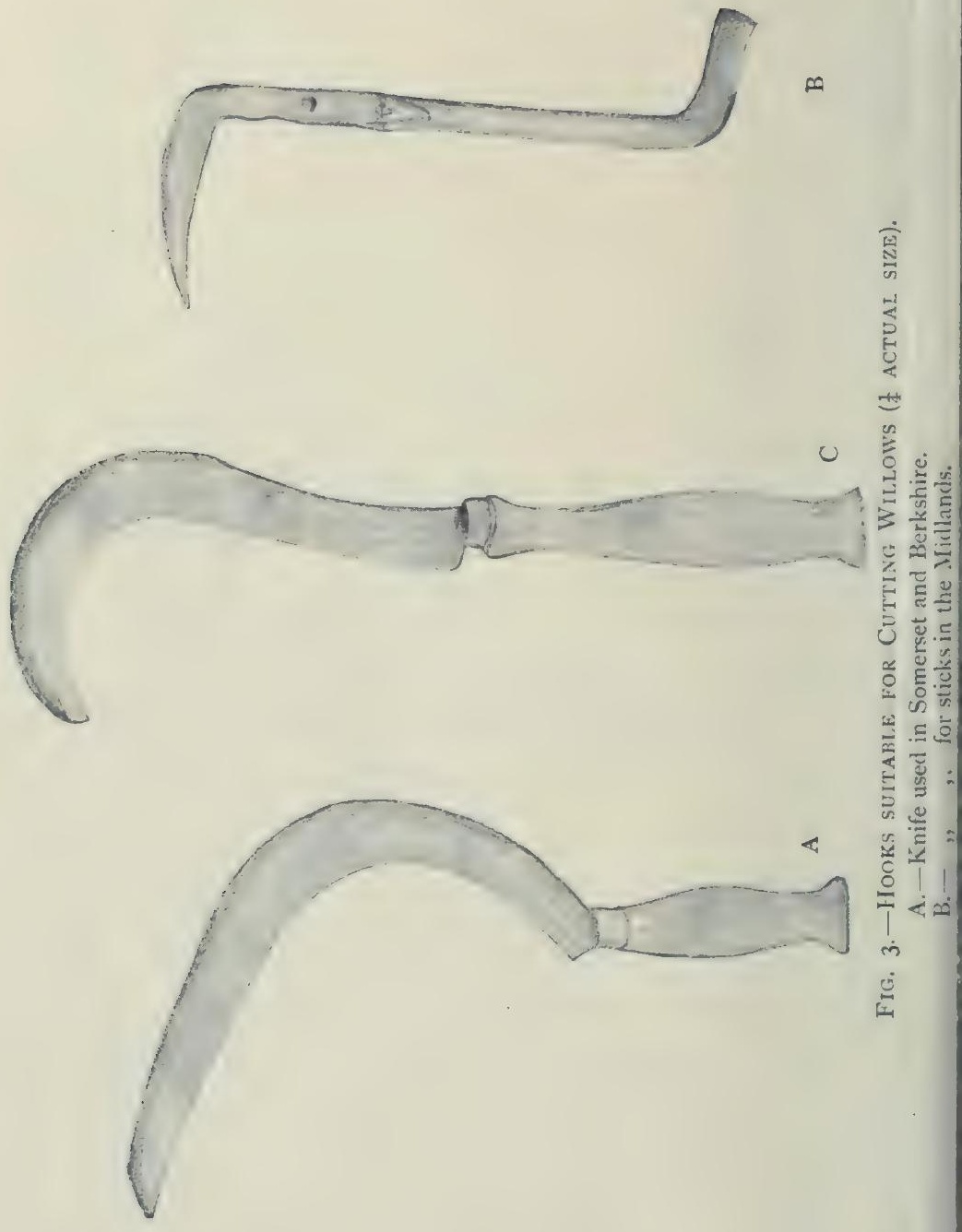




\section{THE CULTIVATION OF BASKET WILLOWS I9}

when cut. There is always a very keen demand for well-grown two-year-old rods of good quality, either as buff or white, for manufacturing strong hampers, such as are largely used in the hosiery-making districts, as well as in Yorkshire and Lancashire. These two-year-olds are required for staking, or lid and bottom sticks, around which the one-year-old rods are worked.

Cutting is usually done by men with knives illustrated (Fig. 3). In no circumstances must this part of the work be performed in a slipshod or careless manner. The knife must be inserted on the outer side of the rods, and cut inwards and upwards, quite close to the head, with a sharp and clear cut, free from split wood or torn bark. When the cutters are careless many small spurs will remain on the head, and since these spurs form the butt end of the rod, much weight of material is sacrificed. Moreover, as the crop is sold by weight, a needless financial loss is the result. The spurs also invariably die off during the next growing season, dead wood accumulates, and still further and longer spurs are left when cutting time again comes round, until in the course of a few years the head, which should at no period be larger than a cocoanut, is frequently found as big as a cabbage. Round this accumulate moss and various fungoid growths, and the bearing capacity of the head is reduced in some instances quite 50 per cent. When some of the spurs live, as frequently happens, they throw off many small and half-developed rods, tending to the earlier exhaustion of the head. Cutting the maiden crop, over which too much care cannot be shown, and on which the future compact head-formation depends, should be done by day workers. Afterwards cutting 
is invariably done on piece-work terms. All sickly heads should be removed each winter, and the vacant places filled by well-grown one-year-olds of entire length, or tall-grown two-year-olds cut off at the start of the two-years' growth. A still better method is to set apart a small plot of ground and grow yearly a sufficient number of each variety for transplanting, in which case the cuttings may be set I2 in. square. The tap root and also the longest and weakest of the fibres should be shortened a little with a sharp knife, care being taken to leave no ragged wounds to bleed when active growth should be in progress. Only one shoot, the longest and strongest, should be left on the head. A healthy transplanted maiden head will never fail to establish itself. In this way the life may be prolonged almost indefinitely. A willow ground cultivated as directed will last fully twenty years in a full-bearing condition, and still be a profitable source of income for ten years longer.

\section{The Maiden Crop}

Good first-year crops are sometimes grown on the best land, but more generally the crop is of little value owing to the plant having to make root development and shoot above at the same time, and at times the crop does not pay for cutting. If allowed to remain on the head, they would only produce poor secondyear rods, and thus the financial result for the second year would also be poor. The majority of growers, therefore, make it a practice to cut the maiden crop during the first winter which follows the planting. The object of this cutting is to give the grower the 
chance of securing a satisfactory crop during the second season.

On the contrary, a well-known grower states that the maiden crop should never be cut until the second year, on the ground that the young plants will have expended little energy in shoot formation and root growth will have been encouraged; but when this is the case the rods are extremely tender, and on account of the plant not having proper root support the rods will be found only suitable for sale as brown, that is, with the bark on. The third-year crop will compensate for all previous loss.

\section{Tying into Bundees and Carting}

As soon as the willow cutters have cleared sufficient ground they proceed to tie the rods into bundles, often called bolts or bunches, with willow bands of regulation sizes. The size varies with each willow area throughout the country, but is constant for each particular district.

In the Midlands the bundles are tied each 36 in. in girth, the band being fixed 8 in. from the butts. Somerset growers tie up in "bolts" of 38 in. The bolt of Berkshire and East Anglia is recognised as 42 in. in girth. In the Isle of Ely and East Anglia the rods are bunched green with a girth of 45 in.

Carting off the ground in many instances presents a very serious obstacle, owing to the uncertainty of the weather and the natural conditions of the soil in the months between December and March, when much of the cutting is done. I have introduced and had in use a special vehicle for twenty years, and have 


\section{OSIERS AND WILLOWS}

found it possible to use it in almost all conditions of the weather, when it was possible for the cutters to work. It is a very lightly constructed vehicle, and the wheels are boxed so that there are no spokes visible, and two iron tyres about $3 \frac{1}{2}$ in. wide by $\frac{3}{8}$ in. thick are placed on each side of the wheel, which enables it to be run over the ordinary macadamised roads without detriment to the wood of which the wheel is formed. The axle is an ordinary Warners patent. The body is raised from the axle by V-shaped supports, and another support of the same character from the centre of the body to the inside flange of the axle. Two loose swing-hooks are placed on the sides for roping the load down. The total weight of the cart is under $6 \mathrm{cwt}$., and there is not the slightest difficulty in drawing off the ground with an ordinary cob loads of from 20 to $22 \mathrm{cwt}$.

Dimensions-

Length inside bottom of body .

- Width ",

Depth

Length

Width

Depth from ground over all

Diameter of wheel

Width

Width over axle caps ft. in.

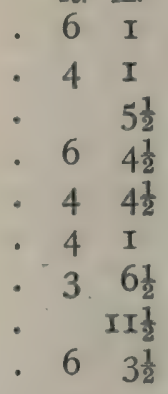

\section{Summary of Directions as to Willow Cultivation}

I. Cuttings should always be used for planting a willow ground. If two-year-old cuttings are used, arrangements should be made twelve months before 
they are required, in order to ensure not only that the requisite sorts are delivered, but that the sets are cut from strong, healthy stock. Some surplus plants should also be planted for replacing any sickly or dead heads that may be found in the ground in the following year. Care should be taken in lifting surplus cuttings not to fracture the roots. Failing two-year-old rods, strong, healthy, full-length one-year-old rods may be used. If two-year-old rods are used, they should be cut off at the top of the first year's growth.

2. After planting, it is of the greatest importance for the first two years that a good loose tilth should be maintained on the top, especially where the soil is strong and liable to crack in a dry period. The rows must be kept clean by hoeing, in order to prevent weeds from choking or retarding the growth of the willows.

3. Willows will not thrive on water-logged land, in peat bog, or in dry soil of a sandy character. The best soil for a willow ground is a strong loam, in a position where it can be flooded at will, though the land must be well drained to provide against an abnormally rainy season.

4. In England willows may safely be planted at any time from the end of October to the middle of April, March being, perhaps, the best time if autumn planting is not resorted to. October planting is in all respects equal to spring planting, and allows other work to be done, such as cutting, sorting, and preparing for the cleaning and peeling season.

5. If possible, a good cultivator should be employed to break up the ground; this is more economical than ordinary digging, and almost as good in its results. This work should be carried out in ample time, to make 
certain of the land being in proper condition for the subsequent planting, for, if the cuttings are stuck into unbroken clods of soil, success can scarcely be expected to follow.

6. The best sorts should be procured, no matter at what cost, for basket willows. The cuttings must be healthy, and not have been retarded in the previous season by attacks of insects, and they must be adapted to the requirements of the market for which the produce is intended. A mixed crop is only of small value, whilst it involves a deal of extra labour at peeling time. Moreover, a little additional trouble and expense at the outset is well repaid, since a willow ground will last from twenty to thirty years if properly cut and cared for. All new plantations should be protected against ground game, for even the shoots of the bitter varieties of willows are not proof against rats, rabbits, or hares.

7. After the cuttings have been planted, the ground around them should be thoroughly trodden down; if this is done in a slovenly manner many cuttings will die.

8. If the bark of a cutting is much chafed or entirely broken, the cutting should not be used.

9. Basket willows will not pay if planted in small, out-of-the-way corners. Any patches of spare land may be planted for poles or timber, but not for basket willows.

10. Willows make good wind screens or nurse trees, and the species known as $S$. repens will grow on the seashore sand-dunes. It forms an excellent shelter for seaside gardens and promenades, and is largely used at the best French coast resorts and golf grounds for that purpose. Some willows will grow on 


\section{THE CULTIVATION OF BASKET WILLOWS 25}

land occasionally overflowed with salt water, provided it is suitable in other respects, whilst slightly brackish tidal water suits all vigorous-growing sorts, as can be seen on the islands and banks of the Thames, Severn, Trent, etc.

II. Willows, when planted on the banks of rivers, possess an additional value by preventing denudation; their long, fibrous roots have great range and tenacity, and the shoots, if cut every two or three years, can be readily sold as sticks.

I2. The inclusive cost of planting good-quality basket willows was before the war about $£$ I 5 s. per thousand or a little over, based on I9,360 plants per acre, the number necessary if planted 18 in. by $I 8 i n$., which is the best distance for the choicer sorts.

I3. All cuttings should be inserted in the ground from Io in. to Ir. in.

I4. The number of cuttings required for an imperial acre is as follows :-

Planted 16 in. by 16 in. I 8 in. by 18 in. 20 in. by 20 in. 22 in. by 22 in. 24 in. by 24 in. 27 in. by 27 in. 30 in. by 30 in. 36 in. by 36 in.
24,502

- 19,360

- I5,68I

- 12,960

I0,890

- 8,604

- 6,970

- 4,840

I5. When cuttings are planted with a view to growting timber trees, all the first-year shoots should be cut to the ground, and any defective or crooked shoots removed at the end of the second year, leaving straight, clean stems to grow on for timber. 
I6. Pollarding a willow destroys its value as timber suitable for bat-makers. The produce from a pollard tree can only be used for fencing purposes; moreover, the head harbours all kinds of noxious insects, and wet and frost soon destroy the heart of the trunk. 


\section{CHAPTER II}

\section{EXPENSES AND RETURNS}

\section{Cost of Cultivation and Yield}

THE cost of preparing the land and establishing a basket-willow holt varies much more than in the case of the ordinary farm crop; consequently there is also a wide variation in the returns per acre. The initial outlay is very heavy, and in some cases $£ 12$ per acre is expended on double digging alone, but ploughing is cheaper and is probably quite satisfactory. It is important to bear in mind that a willow ground poorly managed will not pay, but well managed will return good profit. Willow growing certainly requires an exact knowledge of the nature of the land, the requirements of the willow plants, the treatment of the rods, and the marketing of the same.

The rent of the land too varies considerably. In the Somerset area the rent of willow-growing land is generally between $£ 4$ and $£ 5$ per acre, and little can be obtained at a lower price. In the Soar Valley and Trent Basin the rent ranges from $£ I$ IOs. to $£ 2$ IOS. per acre when the ground consists of several acres. Higher rentals are paid where the ground is less than an acre. In the Isle of Ely the rent is nearer $£^{I}$ to $£ \mathrm{I}$ IOs. per acre. In Berkshire much of the willow land is of little value for any other purpose, but in the best willow-growing districts in that country the rent ranges from $£ I$ IOS. to $£ 3$. 
It is now proposed to indicate the approximate cost of preparing, planting, cultivating, and cutting per acre, and to give estimates for the probable yield for the first three years.

In estimates of this sort very great variations are possible in the cost of labour, rents and rates, and, what is of even greater importance, in the cost of the cuttings. These were purchasable at from Ios. to $£ I$ per IO00, before the war, and the number required may vary from 24,500 per acre if planted $I 6$ in. by $I 6$ in. to only 4840 when set out for the purpose of growing sticks. The following particulars should, however, enable any intending grower to estimate, approximately, the cost to him, according to local conditions. The figures for cuttings refer to selected healthy cuttings about 12 in. long, true to name, and of the best varieties of triandra, varieties costing I5s. per I000 at the grower's.

The first column represents labour at a wage of £I 5s. per week. The second column, which represents the equivalent cost in the spring of 1918 , is based upon the foreman's labour of $f_{2}$ a week and ordinary willow-ground workers at $f I I 7 s$. per week. The figures are more or less approximate from the fact that no extensive planting has come to my notice this season.

\begin{tabular}{|c|c|c|c|c|c|c|c|}
\hline \multirow{3}{*}{\multicolumn{2}{|c|}{ Ploughing old T Turf ner acre }} & \multicolumn{3}{|c|}{ Pre- } & \multicolumn{3}{|c|}{ In 1918} \\
\hline & & & & & & & \\
\hline & & & & 0 & & & \\
\hline $\begin{array}{l}\text { 19,360 Cuttings (18 in. } \\
\text { including packing and }\end{array}$ & I8 in.), & & & & & & \\
\hline Planting, if let by the pi & & & $\begin{array}{l}0 \\
5\end{array}$ & $\begin{array}{l}0 \\
0\end{array}$ & & 10 & \\
\hline First year-hoeing four & les over & & Io & o & & Io & \\
\hline Rent and Rates . & - & & I5 & o & & $I_{5}$ & \\
\hline Cutting and Carrying of & e & I & o & o & & 5 & \\
\hline Interest on outlay & . & I & 5 & o & & 12 & \\
\hline & & 26 & 15 & o & & 17 & \\
\hline
\end{tabular}


The returns to be set against this expenditure vary very much, and are dependent on the season. Some land planted at Barrow, Leicestershire, with Black Maul, Black Germans, Mottled Spaniards, and Long Skins, produced two tons to the acre, and these were sold at $£ 42 s .6 d$. per ton on the ground after it was cut, whilst in another case many acres were planted the following spring, and, owing to the very hot and dry summer, the crop did not pay for cutting. This is the usual risk experienced by farmers, but it may be desirable to state that whilst willow growing is indisputably a profitable undertaking, it is nevertheless always more or less risky in the first year. When the heads are once established they go on yielding for many years. 1

The second year's outlay is much reduced, whilst the returns are much greater and involve less risk, owing to the plants having made a liberal growth of root during the first year, so giving additional support to the shoots :-

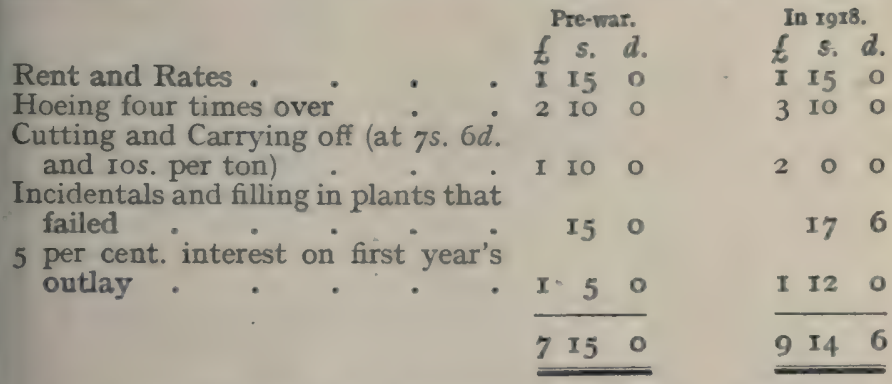

The returns may be estimated at four tons of green rods to the acre, sold in the Midlands at $f 5$ per ton in I9I5-I6.

1 The above figures deal exclusively with the crop when sold as green. 
The third-year conditions for the grower greatly - improve, and the expenditure may be regarded as typical of that for the next twenty years :-

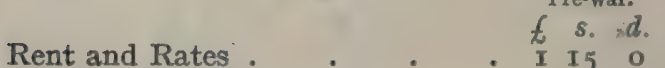
In $x 978$.

Hoeing three times : $\quad x$ ro 0 f s. d. Cutting and Carrying off $\quad \cdot 250$ Incidentals, filling in, etc. . TO 0

5 per cent. interest on first year's , outlay'.

$$
\begin{array}{ll}
150 \\
\hline 750 \\
\hline
\end{array}
$$$$
\begin{array}{rr}
0 & 0 \\
12 & 6
\end{array}
$$

\begin{tabular}{l}
150 \\
\hline 750
\end{tabular}

The returns should be six tons of green rods at $£ 5$ per ton (this being an average price for first quality and growth), or $£ 30$ in I9I5-I6.

By this time the crop is at its best for quality, and it should remain good for many years, provided proper care is taken and reasonable seasons prevail. Much heavier yields in certain exceptionally good seasons have been known; in fact, twelve tons to the acre of green one-year-olds have been cut, though such a yield is seldom obtained, and when it is the yield is invariably far less the following season, owing, no doubt, to the abnormal drain on the plants.

The net cash results as shown thus work out as follows, taking present-day figures $(I 9 I 7-I 8)$ as a basis for calculation :-

Expenditure.

\begin{tabular}{|c|c|c|}
\hline $\begin{array}{l}\text { First year } \\
\text { Second year } \\
\text { Third year }\end{array}$ & $\begin{array}{r}t \\
33 \\
9 \\
9\end{array}$ & $\begin{array}{l}s . \\
17 \\
14 \\
12\end{array}$ \\
\hline & 53 & 3 \\
\hline
\end{tabular}

Receipts.

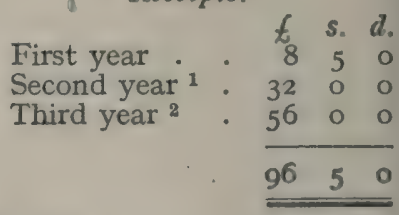

1 Providing the maiden crop was cut.

2 A crop grown at Mount Sorrel, Leicestershire, which 


\section{Cost of Cutting the Crop and Carrying off}

Although the following prices apparently show great variations, the actual net results are very much the same in whatever district the work is undertaken, it being a question entirely whether the bundles are tightly or loosely tied and the height that the cutter fixes his band from the butts. Capable cutters in any of the districts named, will during the short days of the cutting season earn with a full week's employment from $£^{2}$ to $£ 2$ Ios. Very expert men considerably exceed this amount in the longer days of the early spring. The system of payment and the methods of cutting vary considerably in each of the districts in which willows are mainly grown.

In the Midland Counties embracing Leicestershire and Nottinghamshire, 35 . per score was the price paid in 1918 for bundles 36 in. in circumference, with the band about 8 in. from the butt. In the Isle of Ely the price was $4 s$. per score, and the size of the bundle 45 in. In other parts of East Anglia $45.8 d$. to $5 s .6 d$. per score was paid-according to the size of the crop-for bundles 42 in. Berkshire was paying $6 s$. to $7 s$. per score for bundles 42 in. In Somer-

turned off seven tons to the acre, realised $£^{8}$ per ton in 1918 when cut and bundled as grown. The working quality of this material, we understand, was of the best. In East Anglia, where the crops on the whole in 1917 did not do well, as much as fro per ton was paid for well-grown best quality Long Small, Threepenny, and Small Middlesboro', but this additional price is only about equivalent to the Barrow sale, because the Small, the Large, and Rough have all been thrown out, and of course will not realise anything near the same price. In both instances the material was bought for buffing.

"Dicky Meadows" have sold freely by auction at from $£$ Io to $€ 5^{2}$ per ton in the season of I917-18. 
set for $3^{8}$ in. bundles (weeds included) the price paid was $5 s .6 d$. per score. In Lincolnshire the system usually adopted is to pay by the chain of $22 \mathrm{yd} .-I_{2} \frac{1}{2} d$. per chain. This system is also employed in Lancashire, where the payment runs from $2 d$. to $2 \frac{1}{2} d$. per chain, the price being entirely dependent upon the fully planted condition or otherwise, and weight of the crop.

Another common way of letting by the piece is to pay $7 s .6 d$. (pre-war price) per ton for a one-year-old crop, including the carrying of the bundles to various points on the bed for collection by the carters. The prices vary according to the sizes of the rods, the larger varieties being the cheaper. The last-named manner of piece-work obviates all dispute as to whether the bundles are tied up tightly or loosely. 


\section{CHAPTER III}

\section{VARIETIES OF WILLOWS}

$\mathrm{MuCH}$ has from time to time been written on the botanical side of this subject, but such information is of small practical use to growers or workers.

The description given below of the choicest known varieties of willows for basket-making purposes, is, therefore, written exclusively for the guidance of the practical grower, and not from the botanical point of view. The general market prices will be found attached to some of the choicest and best varieties, grown under the best conditions, for Leicestershire and Nottinghamshire productions. These prices may scarcely be realised for many years, but owing to the great shortage of labour associated with the war very considerable areas of willow ground have become derelict and overrun with weeds; and seeing that this equally applies to France, where willows of equal quality are produced, it is reasonable to suppose that the best willows, though they may not continue at these present fancy prices, will for a number of years command extremely profitable and lucrative prices. The varieties to which prices are not fixed are of a more ordinary kind, and, generally speaking, do not realise anything approaching the prices given for the best sorts. 


\section{SALIX TRIANDRA}

This is a species embracing numerous varieties, known to the basket-maker in some districts as fine tops, in contradistinction to the many varieties of the common osier (S. viminalis) which are known as full tops or soft rods. The former species supplies the varieties most suitable for peeling white or buff as one-year-olds. Many varieties of triandra are less suitable for two-year-olds, owing to closeness of the grain of the wood and the limited growth made in one season by the choicest sorts. Some of the largest-growing varieties of this group are more open in the grain, and consequently better suited for providing the larger rods required by hamper-makers. After standing on the head three years this species sheds its bark, a feature not common to other kinds of Salix, and perhaps affording the readiest method of identification. All varieties of this species thrive on a cool, strong loam, and make the best growth in a wet season. In a dry period they are very liable to honey dew, green fly, and gall attack.

The following are varieties of S. triandra :-

"Black Maul," a variety believed to have been brought prominently to the notice of the trade by a practical worker named Maul in Leicestershire, is one of the best willows for all kinds of baskets subjected to long and hard service. It is extensively and chiefly grown in Leicestershire and Nottinghamshire; shoots, $4 \mathrm{ft}$. to $6 \mathrm{ft}$. 6 in. long; requires a rich, loamy soil, with strong, cool subsoil; is a heavy cropper, and always realises good prices-before the war $£ 4$ to $£ 5$ per ton as green one-year-old (in I9I7 up to $f 8$ ), and $£ 24$ to $£ 26$ per ton (in I9I8 from $£ 60$ to $£ 85$ ) as 
white or buff. Plant 18 in. by 18 in. For the first two years this willow has a tendency to grow curlybutted (with a bend at the butt-end), but as the heads get established and the produce heavier, this objectionable feature disappears. Consequently close planting is recommended in order to secure a straighter growth.

"Black Italian," a superior and harder willow, thrives best on a damp, alluvial loam, and its fertility is increased by temporary floods. A "shy" cropper, it is not extensively grown, except on land especially suited to it, when it will produce six tons of one-year-old green to the acre. This realises high prices, and is much sought after by makers of the finest baskets or chairs in buff or white. As buff, its colour is a rich, dark gold, and it whitens equally well. $£ 26$ per ton was not, before the war, an unusual price for white or buff. In IgI8 it fetched $£ 60$ to $£ 85$. Shoots, $3 \mathrm{ft}$. to $6 \mathrm{ft}$. Plant $I 8 \mathrm{in}$. by $I 8$ in.

"Black German" ranks amongst high-class willows, and is easily recognised by a wavy appearance in the growth of the shoot. Less hard than some of the varieties, it is suited to a medium loam with good drainage; it will resist blight and thrive through a dry period better than many other varieties of S. triandra. Shoots, $3 \mathrm{ft}$. 6 in. to $6 \mathrm{ft}$. 6 in. long, a heavy cropper, and straight at the butt. This willow often cuts six tons to the acre, worth as green $£ 4$ per ton, or as buff or white $£ 25$ to $£ 26$ per ton (in I9I8 from $£ 60$ to $£ 80$ ). It does not strip well for white from the water, and peels best when cut from the head about May $I$. Produces a good buff. Plant 18 in. by 18 in.

"French," like many of the varieties of the triandra species, produces both light and dark coloured bark A superior slender working willow; shoots, from $4 \mathrm{ft}$. 
to $6 \mathrm{ft}$. long. Equally suitable for white or buff. Thrives on upland soil, and does not require so much moisture as many other varieties of the triandra. A liberal producer, and ready seller at good prices. As green it realised $£ 4$ IOs, to $£ 5$ per ton; white or buff, $£ 24$ to $£ 26$ per ton (in I9I8 $£ 55$ to $£ 60$ ). Plant I8 in. by $I 8$ in. (This must not be confused with the "French Osier" S. viminalis.)

"Pomeranian," a variety imported and highly prized by the late Mr. William Scaling. A high-class willow closely resembling "French," less vigorous in growth, but harder in quality; an ideal willow for straightness; long and slender; shoots average from $3 \mathrm{ft}$. to $5 \mathrm{ft}$.; admirably adapted for the finest willow work. Equally suited for white or buff, and a ready seller at very high prices. As white, it had been known to realise $£ 34$ per ton before the war, and sold readily at $£ 95$ in 1918 . Plant 18 in. by 18 in.

"Counsellor," first brought prominently into the trade by one of the oldest wholesale willow-working families in England named Mills, of Leake, Leicestershire, who employed this willow, which at that time was the best variety known, in the manufacture of all kinds of flat skein work, such as chair-back screens, washstand screens, table mats, etc. It is one of the best willows known, but has been neglected in its cultivation, because that branch of the business to which it was adapted has fallen on evil times and has been largely captured by the French. It is suited to a rich cool loam, and makes a growth of from $3 \mathrm{ft}$. to $5 \mathrm{ft}$. in the season. It yields a beautiful coloured buff and an equally good coloured white, extremely tough, and grows straight, and in many ways similar to the "Pomeranian," excepting that its bark is of a 
decidedly dark greyish colour. I am inclined to think by its general habits and growth that it is a darker skinned variety of the "Pomeranian," the skin of which is light. A noticeable feature of the triandra species, is that many of the varieties produce a light and dark skin. The "Counsellor" is well worth propagating owing to the extremely high price it commands. In I9I8 this willow sold most freely at $£ 65$ per ton, white, and $£ 70$ per ton, buff. Plant I 8 in. by 18 in.

It should be pointed out that the sales which are here referred to are exclusively of Nottinghamshire and Leicestershire material. The same prices are unrealisable for material grown in any other part of England. This is entirely due to the soil conditions of the areas in which these willows are grown, yielding a result which is not found in any other part of the country. Although varieties have been transplanted from these districts to many other parts of England, the working quality is very much below the production of the special districts referred to above.

"Brilliant," a variety from the south-west of France, first brought to this country by myself in the spring of Igr6. It has obtained its name "Brilliant" from the fact that when whitened it has an unusually bright clean appearance. It does well on alluvial soils with a heavy tendency. It is a heavy cropper, and makes an annual growth of from $4 \mathrm{ft}$. to $6 \mathrm{ft} .6$ in. Plant 20 in. by 20 in.

"Sarda," another French rod discovered and brought to England at the same time as the preceding one. This willow in the districts to which it is indigenous makes the longest and slenderest rod of any of the triandra varieties. Its working quality 
ranks amongst the first, and although it attains the height of $7 \mathrm{ft}$. 6 in. and frequently above, its Small is quite of a good working quality. It cannot be regarded as a heavy cropper, which probably accounts for the unusual quality of the Small, and will when on the market command one of the top prices. A rod that it is certainly well worth cultivating where the soil suits. It was found growing on a strong marl, and probably will do equally well under the same conditions in this country. Plant 20 in. by 20 in.

"Mottled Spaniards," the best of the several rods known as "Spaniards," and quite different from a rod called by the same name and grown in East Anglia. Is easily distinguishable by small red blotches, producing a mottled appearance on the bark on the upper part of the rod, when the growth is completed and the wood ripe. A heavy cropper; shoots, $5 \mathrm{ft}$. to $7 \mathrm{ft}$. 6 in. long; fairly sound quality; makes useful two-yearolds; suited to all general work; prefers a damp, cool warp or loamy soil, well drained; and makes equally good white or buff. Plant 20 in. by 20 in.

" Lincolnshire Dutch," a vigorous grower closely resembling "French," described above, and chiefly grown in the waterbasin of the Trent (Gainsborough district); much prized by growers of that locality as a good cropper. Thrives well on a heavy warp land, subject to freshets of water. Not regarded by the high-class basket-maker as a first-quality willow. Shoots, $4 \mathrm{ft}$. to $6 \mathrm{ft}$. 6 in. long. Plant $18 \mathrm{in}$. by 18 in. . "Stone Rod," the hardest-wooded of the triandra species, makes the choicest white or buff. Its natural defect is that it grows so bent at the butt-a feature associated with all the very best quality rods. This 
can be partly counteracted by close planting, which compels the shoot to apply upwards for light and air. This willow thrives in the valley of the Severn and some parts of Gloucestershire and Somersetshire. It has been tried on several kinds of soil in Leicestershire, but with comparatively little success; it is regarded as a "shy" cropper, but very valuable. Shoots, from $2 \mathrm{ft}$. to $5 \mathrm{ft}$. long. Suited to a damp, alluvial, warpy, clay soil. Plant $I 6$ in. by $I 6$ in. Worth in IgI8 fIoo a ton when graded into three sizes.

" Rayns's Ten-feet," a vigorous and heavy cropper of the Spaniard class. Attains a length of from $6 \mathrm{ft}$. to Io ft., and is principally employed for white hampers. Suited to a damp, cold loam. Plant 20 in. by 20 in. for one-year-olds.

"Black Holland," one of the largest and longest of this species, is believed to have been brought by the Dutch and planted first in the East Anglia low country, where it thrives better than on the water-basin of Leicestershire and Nottinghamshire. On a favourable soil it is a vigorous and heavy cropper. The shoots are $6 \mathrm{ft}$. to $8 \mathrm{ft}$. long, and it makes an excellent twoyear-old white. Grows best on strong warp land. Plant 22 in. by 22 in. for one and two years' growth, or, if for covert purposes, $24 \mathrm{in}$. by $24 \mathrm{in}$. As brown or white for large and strong gardeners' baskets it is much sought after. If the shoots are left on the head for three-year-olds they make excellent sticks, for which there is an ever-growing demand, either as brown, white, or buff, and they command good prices.

"Glib Skins," a name given by growers in the East Anglia fen country to a variety closely allied to the "Brown Norfolk," is largely grown in Hunts and the Isle of Ely. It is regarded as an excellent willow 
for all kinds of market gardeners' baskets. A heavy cropper, and suited to yery damp warp lands with reasonable drainage. Shoots, $5 \mathrm{ft}$. to $7 \mathrm{ft}$. 6 in. long. It is often attacked by fly, which greatly reduces its market value. When the crop is sound it makes a good second-quality white, and yields a satisfactory return. Plant $22 \mathrm{in}$. by $22 \mathrm{in.}$ If the shoots are left on the head for three years' growth they make excellent sticks.

"New Kind" (light and dark), often called "Norfolks," is one of the best of the larger-growing varieties of $S$. triandra and a very heavy cropper. It is suitable for either white or brown, and as brown is mainly used for all work that requires a superior rod, i.e. fitching, handling, and tying. It always commands a good price and a ready market in any district where brown goods are made. Well suited for growers who have no convenience for whitening. Shoots, $5 \mathrm{ft}$. to $8 \mathrm{ft}$. long. Suited to a damp, heavy loam or warp land. Plant 22 in. by 22 in.

"Long Bud" is chiefly grown in Berkshire, where it enjoys a high reputation for quality. This rod when grown in Leicestershire appears to be identical with the rod known as "Dark New Kind." It is a very heavy cropper, and finds a profitable market. It is classed amongst the first quality of the large varieties of the triandra group. Shoots, $5 \mathrm{ft}$. to $8 \mathrm{ft}$. Suited to a heavy loam. Plant 22 in. by 22 in.

"Champion Rod." - This name is applied to a variety largely grown in Somersetshire, where the soil seems to suit it well, in view of the great length which it attains, up to $9 \mathrm{ft}$. The middle and larger sizes make a moderate-class white.

Salix amygdalina.-This is extremely difficult to 
differentiate botanically from S. triandra, and in fact by some authorities is considered to be a variety of S. triandra. So far as the working quality is concerned, the following three varieties are equally good, and belong "to the fine-top class: "Brunette Noire," or Black; "Grisette Droite," or Straight; "Grisette Courbe," or Bent. These are of French origin, and were first brought to this country by myself in Igro. They are of excellent quality. The lengths attained are : Courbe, about $5 \mathrm{ft}$.; Droite, $6 \mathrm{ft}$.; and Noire, $7 \mathrm{ft}$. The Courbe variety requires a damp, rich alluvial loam or clay, whilst the Noire and Droite appear to do well on a cool loam. Plant, I8 in. by 18 in.

"Trustworthy." - This is a tall and vigorous grower, and frequently attains a length of $7 \mathrm{ft}$. to $8 \mathrm{ft}$. It is grown in Suffolk and Berkshire, and is well adapted for market gardeners' requirements. The small of this variety is exceedingly soft and seldom whitened. When grown under similar soil conditions at Loughborough it is not distinguishable from the rod so extensively grown in Somerset, known as the "Champion Rod." Plant 22 in. by 22 in.

" Whissenders," a variety grown extensively on both light and heavy soils of the Trent Valley. It is regarded as a good variety because of its productiveness and quality as buff, white or brown. Its rods are of the light class closely resembling those of " Early Dutch," but it differs from the latter in the greater length of shoot which it ultimately makes (5-6 ft.), and may be distinguished from other triandra varieties by the undulatory and unevenly serrated character of its leaf margins. Plant 20 in. by 20 in. 


\section{Salix viminalis, OR COMmon Osier}

This important species embraces many varieties, which differ very widely in their working qualities; in fact, many are not worth cultivation. Viminalis is a far more vigorous and hardy species than triandra, and is commonly known amongst basket-makers as a full-top or soft rod, carrying as it does a more uniform size to the top than either triandra or purpurea. It is distinguished by the strength and length of the shoots, which, in some instances, reach II ft., and even longer, in one season. All varieties of this species are very accommodating in their habits, and generally do best in a dry season, providing the soil is fairly strong and cool; in fact, they will grow in almost any soil, from drift to clay, and make a vigorous growth in a wet period, although the quality of the wood is then deficient, owing to the rapidity of the growth.

" Long Skin" (perhaps " Long Skein " would be the more correct term), when it is true to kind, is the closestgrained and the hardest-wooded of all the viminalis species, and makes the toughest skeins; but it gives rise to more contention with buyers than any other willow grown, since many growers who possess a goodquality osier persist in describing it as "Long Skin," in the hope of realising the fancy prices sometimes paid for the true sort. Although a vigorous grower, it seldom yields a smooth crop, being frequently damaged by the larvæ of insects, which cause the top of the rod to throw out side-shoots. This defect, commonly known amongst basket-makers as rose-top, greatly reduces its value, and the variety is not grown extensively, owing to the uncertainty of the crop being smooth. Shoots, $4 \mathrm{ft}$. to $6 \mathrm{ft}$. 6 in. Good for white 
one- or two-year-olds, but scarcely equal to secondquality triandra for buff, unless grown on a strong clay soil. Plant 20 in. by 20 in.

"Brown Merrin " is a more lengthy rod than "Long Skin," with the additional advantage that the fly does not attack it nearly so much; moreover, it generally grows smooth. When grown on strong clay it makes a good second-quality white one-year-old, or first-quality two-year-old, or excellent brown. Shoots, $4 \mathrm{ft}$. to $7 \mathrm{ft}$., and a heavy cropper. Plant 20 in. by 20 in.

"The French Osier," first imported from France by myself, is the best of the viminalis group grown in that country. In the North of France it is greatly prized as a skein rod. Shoots, $4 \mathrm{ft}$. to $7 \mathrm{ft}$. 6 in. Requires a strong loam bordering on clay. Plant 20 in. by $20 \mathrm{in}$. It should be understood that the term "Osier" is applied exclusively to the varieties of S. viminalis ; thus, "French," described on p. 35, and "French Osier" are quite distinct.

"Yellow Osier," a fair cropper and invariably smooth, has been observed year after year to escape all attack by fly. The larger sizes make good secondclass white, and the full crop excellent brown, when grown on strong upland or meadow clay soil. Shoots, $4 \mathrm{ft}$. to $7 \mathrm{ft}$. Plant 20 in. by $20 \mathrm{in}$.

" Black Top Osier."-A very good class osier on soil adapted to it. Does best in a good loam. Attains on an average about $7 \mathrm{ft}$. to $7 \mathrm{ft}$. $6 \mathrm{in}$. in one season, and makes an excellent skein rod. Will make a thirdrate white, but the small is too soft for peeling. Plant 22 in. by 22 in.

" Reed Osier," so called from its great length and straight growth, and the "Continental Osier," another variety similar in many respects, are the most vigorous 
known; they are very suitable for holding up river banks, for wild-bird coverts, or low, out-of-the-way places, and often reach a length of II $\mathrm{ft}$. and over in one season. After the heads are well established little attention is necessary, the foliage being dense enough to destroy the vegetable growth underneath. These two varieties provide the straightest and longest sticks grown, and when left for two or three years' growth command a brisk demand amongst all makers of transit hampers and basket furniture-which latter business has developed into a great industry in this country, and which in the past has been mainly supplied from Germany. When cut as one-year-olds they make good brown, and supply a larger proportion of staking than any other variety. Plant for one-year-olds, $22 \mathrm{in.}$ by $22 \mathrm{in}$.; if for sticks, 26 in. by 26 in.

"Meally Top Osier."-Another very vigorous-growing variety, chiefly to be found in Somersetshire and some districts of the Eastern Counties. It is best suited to a heavy soil and frequently attains Io to II $\mathrm{ft}$. in one season. Cannot be recommended for white but makes excellent brown for market gardeners' work, and equally good sticks which can be whitened or buffed. Plant 24 in. by 24 in.

A strong loam or clay soil is necessary for all the varieties recommended for sticks because of the great length to which they attain; otherwise the action of the wind during the winter season would so loosen the roots in a lighter soil that there would be a great risk of them dying. Are unsuitable for peeling white as one-year-olds, but make excellent white or buff sticks.

All the viminalis varieties are characterised by their heavy yields, and most by their adaptability to all soil conditions, and the low quality of the rods which 
they produce. When one-year-old the rods are used as brown in the making of the coarsest kinds of basket ware. As two- and three-year-olds the rods, called sticks, are used as the main supporting parts of the heavier classes of hampers and basket furniture.

\section{SALIX PURPUREA}

Salix purpurea, or the bitter willow, embraces many varieties, the best of which are the most slender for their length of all willows, and it also includes the two extremes in size. The smallest, known as "Dicks" or "Red Buds," is one of the toughest willows known, whilst others grow to $9 \mathrm{ft}$; they are easily recognisable, since all are yellow on the inside of the bark, are very bitter to the taste, and show red eyes at the spring growth. Rabbits and cattle will seldom touch them unless under great stress of hunger.

The purpurea are unsuitable for white. Some of the varieties make excellent buff, to which reference will be made under their respective headings.

" Kecks," or "Welch," is a long, slender, and very tough rod, and one seldom attacked by ground game, owing to the extremely bitter character of the bark. This variety invariably grows quite smoothly, thrives equally well under dry or wet conditions, and has never been known to be blighted. Shoots, $3 \mathrm{ft}$. to $7 \mathrm{ft}$. Plant 18 in. by I 8 in. Makes a good light-colour buff. It is used for binding purposes by nurserymen and market gardeners, but the latter now prefer one or other of the alba class for that purpose because of the more pleasing colour of the bark.

"Welch."-This was a variety supplied to me 
by the U.S.A. Government in March I9Io, at which time it certainly differed from the "Kecks" or "Welch," known here in the outward appearance and colour of its bark, but after being planted for three years the apparent difference-as in so many instances of the kind-entirely disappeared, and they were undistinguishable from the English variety. A similar rod in Berkshire and Gloucestershire is called " Goldstone."

"Dicky Meadows," or "Red Buds," supposed to have been first cultivated by a man of that name in Lancashire, is a variety which runs along the ground like strawberry runners; it is a very beautiful rod, wiry, and a heavy cropper, but very difficult to keep clean, since the weeders must work unshod and with their feet clothed in some soft fabric in order to avoid bruising the shoots. Unsuitable for white, but makes very choice buff, and is now largely used in the making of tea and luncheon baskets; for all classes of fine buff goods it has no equal. Shoots 18 in. to $4 \mathrm{ft}$. 6 in. Will do equally well on drift or heavy soil, and is not affected by dry or wet seasons-a feature peculiar to all varieties of purpurea. Plant 16 in. by 16 in. This variety this year (IgI 8 ) is making most extraordinary prices, and is selling as green at $£ 52$ per ton. Many instances are on record of lots being sold to the users when buffed and graded into their five sizes at from $£ 90$ to $£$ I50 per ton.

" Light Dicks" is another varicty in all respects like the above, except that the bark is of a very light colour, and comes into flower somewhat earlier than the "Red Bud." It frequently attains a somewhat larger growth than the "Dicky Meadows." Shoots, I8 in. to $5 \mathrm{ft}$. Heavy hazel soil. Plant 16 in. by 16 in. 
"Dark Dicks," another of the same variety, grows longer than either of the above and upright; it is used for staking and also for skeins. Shoots, $2 \mathrm{ft}$. to $6 \mathrm{ft}$. This variety does best in a very hot season, and is capable of yielding a second-quality white. Soil conditions as for " Red Buds." Plant 16 in. by 16 in.

"Pyramidalis" is a tall, slender rod, sent to me from Germany as one of their best, and classed by a German botanist as purpurea-a doubtful classification, since it makes a good-colour white, which no English purpurea will do. Shoots, $5 \mathrm{ft}$. to $8 \mathrm{ft}$. Plant 20 in. by 20 in.

"Brittany Green," a beautifully slender rod of great length for its substance, was brought by me from France and planted at Loughborough in the spring of I9II, on a rather dry, rich loam, or marl soil, I $8 \mathrm{in.} \mathrm{by} 18 \mathrm{in.}$ In spite of the severe drought of IgIr, it wholly escaped the blight, from which so many suffered, and at the end of July had made a satisfactory and healthy growth. In France it is regarded as a good rod. Shoots, $3 \mathrm{ft} .6$ in. to $6 \mathrm{ft}$. 6 in.

\section{SALIX PENTANDRA}

The three following sorts, viz. "Lumley," "Patent , Lumley," and "American Green," were sent to me by the U.S.A. Forestry Department in March I9Io, and are stated to be the best suited to transatlantic climatic conditions. They gave in IgII a growth of $4 \mathrm{ft}$. to $6 \mathrm{ft}$. under a very dry and trying season, and escaped the green fly, with which the adjoining varieties were badly troubled, owing to drought. They are good croppers but of third-rate quality when peeled white. 


\section{SALIX ALBA}

"Africans." - This variety as grown in England is the better of two kinds largely imported. It does not make the same long growth as in its native country. A rich alluvial clay is suitable. Shoots, $4 \mathrm{ft}$. to $7 \mathrm{ft}$., $3 \mathrm{ft} .6 \mathrm{in}$. to Io ft. in its native climate. A very suitable and excellent willow for warm, humid places. Plant 20 in. by 20 in.

Salix alba var. vitellina.-The variety known as "Golden Willow" is one of the toughest willows grown if used with the bark on in a green state. It is chiefly sold for tie-rods to market gardeners, nurserymen and celery growers, who get their prineipal supplies from the Reading district and Suffolk. Strong, damp, rich soil is required. Shoots, $3 \mathrm{ft}$. to $6 \mathrm{ft}$. $6 \mathrm{in}$. If peeled, the colour is dirty and the rods poor in quality, and when dried for brown the bark goes black in patches, making consequently but a secondrate price in this condition. Plant 20 in. by 20 in.

Salix alba var. cardinalis.-The "Belgian Red Willow" is the best working-quality willow that Belgium produces, but is far inferior to the triandra varieties of Great Britain ; it is a moderate cropper, but the shoots rarely exceed $5 \mathrm{ft}$. 6 in., and they do not make a good colour as white; it finds a ready market with gardeners and nurserymen as green for tie-rods, and is well suited for that purpose. Its great toughness lies in the bark. Plant I 8 in. by 18 in. on a damp loam soil.

SALIX HIPPOPHAIFOLIA (for serwage farm purposes)

Botanically this willow resembles both $S$. triandra and $S$. viminalis and is therefore classed by botanists 
as a hybrid. It is characterised by a green base and a brown top. It is a vigorous growing willow, and a very heavy cropper, frequently cutting more than eight tons to the acre. The willow requires a rich soil, and is, therefore, adapted to the method of cultivation practised on sewage farms. Furthermore, it produces dense foliage which checks the growth of weeds. Its wood is exceedingly hard, and the quality does not appear to deteriorate when grown under sewage farm conditions. Of all the willows tried on sewage farms, this alone has proved satisfactory, producing a rod equal in quality to those produced under ordinary conditions. Whilst growing, the largest rods have a tendency to throw out side shoots, but as these are usually of a tender character, they fall away during the winter season or at peeling time. For all purposes of work where a full top is desirable it is probably unequalled, and it is equally good for white, buff or brown. The shoots are from $4 \mathrm{ft}$. to $7 \mathrm{ft}$. long. It should be planted 20 in. by 20 in.

\section{SALIX WIGSTONIENSIS}

This rod was developed from S. hippophaifolia, but differs in the colour of the bark, being of a red, copperybrown colour. Very little grown, but I have found it an extremely useful rod, making excellent white or buff. Grows $4 \mathrm{ft}$. to $7 \mathrm{ft}$. Requires a rich loam. Plant 20 in. by 20 in.

"Americana" was first introduced here by myself from Silesia, where it is known as "Americana" from the fact that it has been extensively exported from Germany to America. It is a long supple 
willow apparently with a strain of purpurea in it, from the fact that in the spring-time it shows red eyes - a characteristic of the purpurea species. Of moderate working quality, has a good marketable appearance, and may be regarded as a splendid willow for brown because it invariably grows smooth and singularly free from insect attacks. It makes a growth of about $7 \mathrm{ft}$. on an average loam, and is a good cropper. Plant $20 \mathrm{in}$. by $20 \mathrm{in}$.

\section{SALIX DAPHNOIDES}

There appears to be only one willow of this class grown commercially, and because of its violet bloom it is known to the trade as "Violets." The number of shoots to each plant is few, but being a vigorous grower it frequently produces shoots $8 \mathrm{ft}$. to Io $\mathrm{ft}$. long in one season. Such shoots if left uncut until the second year should produce valuable sticks. This willow will do with a poor, strong class of soil. Plant 22 in. by 22 in.

\section{Unclassified Rods}

In addition to the above there are other varieties, known as " Gelsters," " Russets," " Harrisons," " Red Root," all of which thrive without much care if conditions are suitable to their requirements.

"Harrisons" and "Red Root" possess characteristics common to both $S$. viminalis and $S$. purpurea, and may be regarded as hybrids of these. The question of hybridation in willows touches a very 


\section{VARIETIES OF WILLOWS}

controversial point in classification, and nothing really definite has been decided.

In addition to those enumerated, which are the best commercial varieties, there are numerous others which only command a very low price and are not worth the attention of any intending grower to plant, and for that reason are not referred to.

Note.-The prices specified in this chapter are already rendered out of date as these pages are passing through the press. Dicky Meadows (p. 46) cannot now (November I9I8) be bought under $£ 200$ the ton as buff. 


\section{CHAPTER IV}

\section{PREPARATION AND MARKETING}

\section{Preparation of the Rods}

In cases where the grower has no facilities for preparing the willows they are marketed direct from the field as "green." The rods in this condition are heavy, and the freight charges for transit are therefore high. Furthermore, the buyer has to sort out, grade, and prepare the willows in many ways before they can be used by the average basket-maker. Some of the poorer grown and those of inferior quality are at times used green for making the very cheapest-grade baskets used by seedsmen, yeast merchants, etc., and as such baskets are usually non-returnable, the price of green for this class of basket work is very low. To secure the best prices it is advisable to plant only the best varieties, and to prepare for buff or white.

\section{White Rods}

White rods are prepared in the spring after the flow of sap has become active. Cell activity commences in the region of the apices of the shoots and travels downwards. Consequently the upper portions of a rod may be "peelable," while the butt end has the skin still firmly attached to the wood. A backward 
spring suddenly followed by a few warm days causes rapid sap-flow, which is closely followed by development of new wood. Under such conditions satisfactory peeling may not be possible for longer than three or four days for the early varieties. Under opposite conditions the peeling period may last fourteen days when the crop consists of early and late varieties. The period during which the process of whitening rods is possible, can be prolonged by growing several varieties which attain in succession the best peeling condition, as, for instance, Champion Rod, Black Maul, New Kind and French.

\section{Preparation for Whitening}

The several methods of preparation for whitening are known as cutting from the head, couching, pieing, and pitting. All are necessary in the case of growers on a large scale, whose object it is to start peeling at the earliest possible moment and prolong it as late as they can.

Cutting from the Head.-After the greater part of the crop has been cut for buff, or put into the pit or the pie for whitening, the first process is known as cutting from the head. The first willows to peel will be those cut from the heads when bursting into leaf. The time between cutting the early and late varieties is frequently as much as from seven to ten days. The greatest care must be exercised in cutting in order not to allow willows to stand on the head until a new growth begins to form, as this produces a second skin, which shows itself when peeled in fine strips or shreds on the top of the old wood and presents a very 
ragged appearance when worked up. Such "doubleskinned" rods are greatly depreciated in value and useless for good work; moreover, an exhaustion or bleeding of the head results. The correct period for commencing to cut from the head for white peeling cannot be determined by the calendar. It has been known to vary from March Io to May Io. The proper time is when the leaf begins to show or when the catkins appear, for the sap has then begun to flow. On many varieties the catkins appear before the leaf.

\section{Couching}

A limited number of the spring-cut bundles are placed in heaps in definite order on the ground. Usually a layer of bundles is placed with the butt ends all one way, and a similar layer is placed on the top with the butts at about the centre of the bundle forming the bottom layer. This is repeated until the heaps are about six bundles deep. The object is to keep the tops from heating, and to permit the flow of the sap. It will be found a good plan to throw a liberal quantity of water over the whole to aid the sweating and prevent heating; then to cover the heap lightly with old peelings, which keep the willows warm and exclude wind and sun. By the time the material cut and peeled from the head is finished the contents of these stacks should be quite ready for peeling (see illustration, Fig. 4).

\section{Pieing}

If they have plenty of spare ground, some growers instead of couching prefer to put one row of bundles 


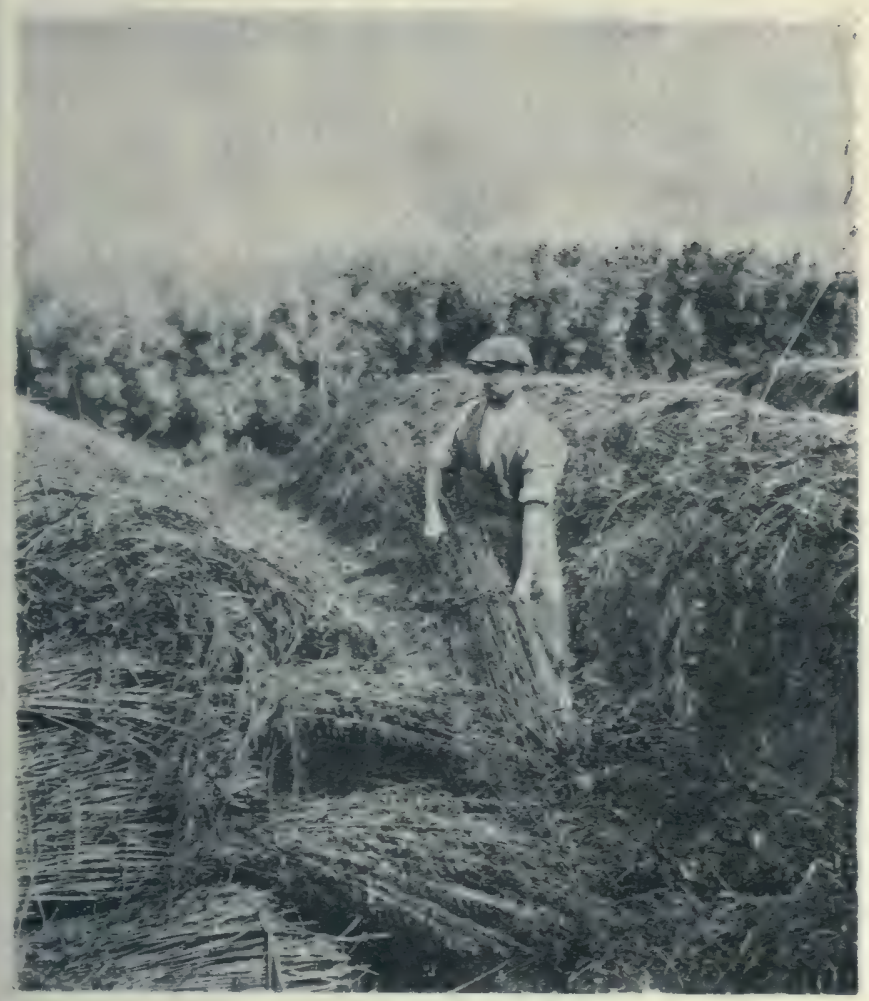

Fig. 4-Rods IN THE Couch. 

on the ground and then place the next row from $3 \mathrm{ft}$. to $4 \mathrm{ft}$. behind, so that the tops of the back bundles wrap well over the butt ends of the row in frontcontinuing this until all are in the pie. The willows are then lightly covered over with old peelings, and watered once or twice a week, according to whether the season is wet or dry. In this manner they will keep in a peeling condition for weeks. The small rods in the bundles must not be allowed to heat, and in order to avoid this, it is as well to turn the bundles over if they are likely to lie for more than two or three weeks. Couching and pieing are only attempted by a few growers, the majority rely on pitting, which is customary in almost every willow centre.

\section{Pitting}

In pitting, the bundles are placed in an upright position in a dyke in from 5 in. to $8 \mathrm{in}$. of water. The rods should not be tied too tightly and all butts should stand level to ensure that they are in the water; light and air should be allowed to penetrate freely. It will be found a good plan to space the bundles into " bays," so that each bay will contain 18 to 24 bundles according to the size of the bundle. If the bundles do not exceed 33 in. round, 24 may be placed in each bay; but if they are 36 in. to 38 in., I 8 bundles will be found quite sufficient.

In pitting it is essential that the water should not be too hard or too cold, and that fresh water should always be passing through. If the water is stagnant, the rods will make a satisfactory growth for a short time and then remain in about the same state for a week or ten days. Afterwards they will gradually turn sickly and 
deteriorate, or frequently get covered with mealy bug or other insect life. When a constant supply of fresh water has been maintained, rods have been known to stand in the pit from March, which is the usual time to begin pitting, to the end of July. Where the amount of available labour is limited, or the season proves to be wet and unsuitable for outdoor peeling, pitting has a great advantage and there is no fear of a double skin being produced. Even with a good sound bottom for the dyke, it is a wise plan to rinse the dirt from the butt ends of the willows in clean water and allow them to dry somewhat before peeling is commenced.

\section{PeEling for White}

The rods are peeled by the hand assisted by " fixed breaks," and women and children are employed for the purpose. Although much time and money have been expended on constructing machines to do the peeling, very little improvement has been made in the process used fifty years ago. The peeler stands by his break, which is fixed to a table or post, with a bundle of green rods at his side, the butt ends all being near the break. The rods are taken separately, the butt end drawn through the break, splitting the skin; the rod is reversed and again pulled through the break. The skin is removed and the rod comes away clean and white.

The process is the same in every district, though the actual breaks used differ in shape and form.

Breaks.-A break in its simplest form consists of two metal blades pressed together by the hand whilst the rod is being drawn through. The appliance 

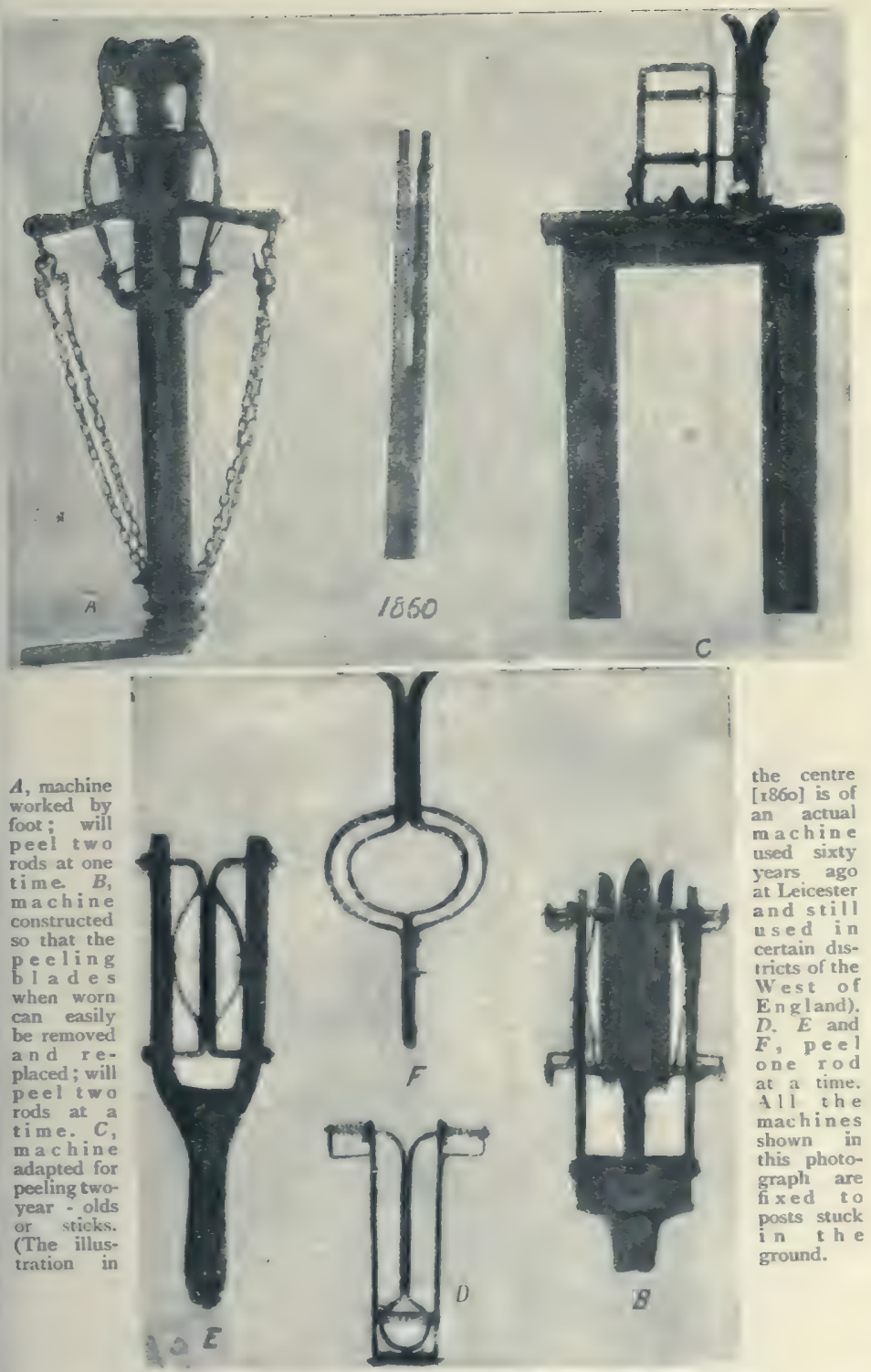

A, machine worked by foot: will peel two rods at one time $B$, $\mathrm{mach}$ ine constructed so that the peeling b l a d es when worn can easily be removed a n d replaced; will peel two rods at a t ime. C, ma c hine adapted for peeling twoyear - olds or sticks. (The illustration in

Ficis. 5 and 6. - Machines and Brakes for Peellng Willow Rods. 

marked I860 in Fig. 5 shows a simple break of this kind which has been in existence for sixty years and is still used in some parts of England. If used carefully the work is done well, though slowly, but often the peeler exerts too much force and splits the rod. In the more modern type the principle used is much the same as in the break described above, but the blades are kept together by a spring so that the operator has both hands free to pull the rod. It possesses the further advantage of exerting a constant. pressure which does not damage the rods. E and F, Fig. 6, represent two breaks of this type, modification of which are generally found most useful by willow peelers. Several more complicated breaks, such as represented by $\mathrm{A}, \mathrm{B}$ and $\mathrm{C}$, have been invented and are usually efficient, but on account of their cost have not yet come into general use.

Drying White Rods.-The freshly peeled rods are dried in the open air by resting them against stretched wire. The wire should certainly be galvanised to prevent its rusting during wet periods. Such rust would stain white rods. I find it better to spread the rods on to a couple of wooden rails fixed $2 \mathrm{ft}$. from the ground. The wind can then exert a drying influence without the fear of staining. The first consideration is a good colour, and in order to attain this, white rods ought not to remain out of doors more than twenty-four hours.

In suitable weather all material peeled before noon should be warehoused the same night, and this can only be made possible by thinly spreading it on a couple of rails fixed $2 \mathrm{ft}$. from the ground so that the wind can play underneath as well as on to the top. As good colour is of so much importance, the workers 
should be discouraged from handling rods with dirty hands. The peelers must be taught to lay the rods between pegs, according to their various sizes-usually three, but sometimes four, according to the class of the rods. When dry, the rods are graded, bundled, and stored in a dry house.

The cost to the grower in Somerset who whitens his own crop may be estimated according to the prices current in July I9I6, at $£ I 8$ per ton, made up as follows :-

Three tons of one-year-old green, at $£ 4$ Ios. a ton, will produce one ton of white at a cost for labour of $£ 4$ IOS., i.e. $£ 3 \mathrm{I}_{5}$ s. for peeling and $\mathrm{I}_{5} \mathrm{~s}$. for tying and other incidental expenses. In the past, in the Midlands, white peeling was paid for at a daily wage of Is. $3 d$. to $2 s$. $6 d$., according to the experience of the workers. The tendency now is to adopt the more businesslike method of paying by weight, which ensures the peelers a suitable reward for their labour. In Leicestershire, Lincolnshire and Nottinghamshire peeling is usually done by weight. The peelers sort their oneyear-old rods into two classes, known as hullings and rods, the price being $7 d$. per stone for the rods, equivalent to $£ 46 s$. $8 d$. per ton, whilst the hullings cost Is. $3 d$. per stone or $£$ Io per ton (this was in I9I 7 ). As the hullings represent about one-third of the rods, this works out at approximately $£ 5$ I5s. per ton, to which must be added the labour associated with tying and drying. At one of the principal peeling yards in the Midlands, where the peeling staff exceeds a hundred, objection was taken to any form of piece-work rates, and 20s. a week of 44 hours was paid to the women in the spring of I9I8, resulting in the cost exceeding that of any previous year. 
In the Midlands I have utilised my steam installation for buffing in a novel manner as follows for forcing the rods to grow in the winter months. A pit, 9 in. deep by 5 yds. wide and ro yds. long, was built of concrete and bricks. The width was divided into three sections, each of the two outer being 2 yds. wide, whilst the centre, of I yd. wide, provided a path. The two outer bays were supplied with a steam-heated pipe, which gave the water a temperature of from $55^{\circ}$ to $65^{\circ} \mathrm{Fahr}$. The water was changed twice a week to ensure a constant supply of fresh water. After the rods had been standing in the water for a little over a fortnight, the sap flowed and the rods peeled satisfactory. As the end of each section became empty it was filled up again with fresh material. By using this process, many tons of rods were peeled three months before they would be ready for peeling under natural conditions. At a time when white is realising fancy prices, this novel method seems attractive. As there is a strong probability that very high prices will be realised for some years to come, this inexpensive method of peeling out of the natural season is worthy of consideration.

\section{BUFFING}

This is the earliest operation that can be undertaken when the willows have fully grown, and may be commenced at any period when the foliage has fallen. Whilst there is no calendar period to indicate this, the wood will usually be sufficiently ripe by the early part of November. Buff rods are produced by boiling in their skins freshly cut rods and those which have 
been left to dry, and then peeling them. In the case of boiling dried rods, it is most important that these shall not be heated in any way, as in that case blotches will be left upon the wood, the labour involved in stripping will be considerably increased, and the value of the rod will be greatly depreciated when peeled. All the heated places instead of coming out an even buff will show light-coloured patches.

The boiling for buffing is done in specially constructed long tanks for some hours. The exact time varies according to the variety of willows under preparation and the class of soil in which it was grown. Thus in the Midlands the average time of boiling is about five hours, but in Somerset a much longer time is necessary if a good buff colour is desired. By boiling, the tannin matter present in the bark is liberated and acts as a dye on the underlying wood, giving it that pleasing colour so characteristic of buff rods.

\section{Varieties suitable for Buffing}

In order to meet the large demand usually experienced in autumn for buff rods, it is essential that growers should plant several varieties, ranging from French to Mauls or Mottled Spaniards. Stacks of green willows soon dry when exposed to the spring winds, and the grower should, if possible, boil the varieties with the thinnest skins first, such as Spaniards. Black Maul and New Kind, having thicker skins, will remain green up to the end of March or April, and S. hippophaifolia will buff well up to the middle of May. These rods have the thickest skins, and if need be can be peeled when the bark has dried by placing them in cold water at the commencement of the boiling. 
The varieties of $S$. viminalis, with the exception of Long Skins, do not make good buff. Long Skins may be left until late in the season, since by reason of their good quality the rods leave the boiling-tank with sufficient colour to be stacked as soon as dry.

Owing to the low percentage of tanning properties, the purpurea varieties are seldom used for buff, and the only sorts in large demand are Light, Dark, and Old Dicks and Kecks. The Light and Old Dicks are eagerly sought after for all articles requiring a small, long, and tough taper rod. The Dark Dicks, being of a larger growth, generally provide stakes or skeins, but, in the event of their not growing large enough, the Kecks are the only other variety suitable to supplement them giving the same shade of colour.

Each of these sorts is best left until the early spring, when the sun begins to exert its influence and materially assists in developing the desired light-golden colour. In the absence of sun it is often necessary to expose these willows on the grass for from two to three weeks, turning them over during that period several times in order to get the required colour and to prevent mildew or black spots appearing, for both those defects materially reduce the market value. If the season is a dry one the rods should be sprinkled with a fine spray of water; sun and air will then produce the necessary colour. It is most desirable that an equal colour be obtained all through the output, and since the sun plays such an important part in producing this, the exposure need not be so long during the later weeks of the peeling as in the earlier part of the season when there is less sun and light.

The whole of these varieties should be boiled in the 
green state, and peeled by the fingers, so as to prevent splitting, which would destroy their value.

Time of Cutting.-Cutting the crop for buffing can be started as soon as half the leaf has fallen, $i . e$. usually about the third week in October. The remainder may be cut after the whole leaf has fallen, and may be stacked in the open without harm to the rods.

Boiling. - The size of the boiling tanks will vary according to the kind of willow and to the number of peelers employed. Four peelers on each side are as many as can work on average rods to advantage. The eight peelers should empty in one day a tank $12 \mathrm{ft}$. by $4 \mathrm{ft}$. 6 in. by $4 \mathrm{ft} .9$ in. deep inside, holding about $30 \mathrm{cwt}$. of ordinary green one-year-olds, which, when peeled and dried, give Io to II cwt. of buff. This size tank will also be found useful for sticks.

In the case of Dicks or any similar small-growing varieties, a tank $7 \mathrm{ft}$. long by $2 \mathrm{ft}$. wide and $2 \mathrm{ft}$. deep (inside measurements) is large enough. In the north-west of England, where the Dicks are largely grown, wooden tanks, of the dimensions above, having a sheet of iron on the underside of the tank, are used. The water is heated by a fire underneath, with a single flue running up a cheaply constructed chimney at the end.

For the grower of ordinary willows the following arrangement will be suitable :- Having decided on the size of the tank, the flue should be run underneath the centre for the full length of the tank, raised or bridged two-thirds of the way along the bottom to save fuel and give greater heat, turned at the end so as to pass along the side and across the front above the furnace door and then along the opposite side and up the chimney. The tanks are made of compressed steel sheets bolted 
together and fitted up with brickwork in such a manner as to leave the flues as mentioned. By this arrangement the maximum amount of heat will be given to the tank before the smoke ascends the chimney.

The tank should have an inside flange at the top in addition to an outside one, in order to keep the wooden sinkers which hold the rods under the water during the process of boiling, in their places.

For continuous use in the Midlands, it is found advisable to work so that all the rods in the tank on any day can be peeled by four o'clock in the afternoon, which is as late as the peelers can see in the winter-time; the fire should then be stoked and the water brought to the boil. This done, the tank should be closely packed with willows, some of the peelings placed on the top to keep in the heat, and the wooden sinkers fixed across under the flange to keep all the bundles immersed. After the willows have been boiled for about five hours, the fire should be banked up and the tank left until the following morning. The water should then be heated to warm the rods ready for the peelers. In Somerset the bundles of willows are placed into boiling water in the tanks at twelve (noon), and the water kept boiling until the evening. The fire is then banked up and left until the following morning, when the willows are removed and peeled. The water is brought to the boil and the tank refilled with willows at twelve (noon). The tanks are thus kept in continuous use for a fortnight, when the fire is withdrawn, and the flues cleaned. The tanks are emptied of water, cleaned of refuse, and refilled with fresh water.

The simple method described above will be found equally good in the case of larger plants. In one case, a range of four large tanks and one small one was 
heated by means of a I2 h.p. Cornish boiler, which not only provided the steam for boiling the water in each tank, but also pumped the cold water from a well for filling both the boiler and tanks and furnished the heat required for drying the buff.

For heating by steam, the coils of copper piping that lie along the bottom of the tank should be hinged, so as to allow them to be raised up either from the end or side for the purpose of removing the sediment which accumulates between the pipes and on the bottom of the tank. Attention to these details will be rewarded by the brighter colour of the buff.

Of the five tanks referred to above, only two had flues fixed underneath, and either or both of these could be fired at a less cost than putting steam on. The object of placing flues underneath is to afford another means of heating in the event of the steam boiler going wrong.

It is preferable to complete the buffing before the bark dries, but if this is not possible, the rods may be buffed by putting the rods in cold water when the bark has set and then by boiling them as indicated above.

The average price for first-quality growth of oneyear-old green in the winter of $1915-16$ was $£ 5$ per ton. Three tons of green when boiled give one ton of buff, and, taking the cost of the coal and labour, including a foreman, to be about $£ 6$ Ios. per ton, the net cost of producing a ton of buff will be $£_{21}$ IOs. The sale price generally shows a good profit.

Tanks for Boiling.-In addition to the two styles described under the heading "Boiling," there are less expensive methods of meeting these requirements. The sizes are entirely dependent upon the area and quantity of material the grower intends to buff annually. A 
simple and effective method for the small producer will be found to answer, by placing out of doors a wooden tank about $7 \mathrm{ft}$. by $2 \mathrm{I}$ in. wide and $24 \mathrm{in}$. deep, made from sound wood 2 in. thick. This should be fitted with a sheet-iron plate underneath the bottom; erected on bricks and a flue fixed as previously described, straight under the centre of the bottom but bridged two-thirds along, and a cast-iron chimney supported as circumstances will present themselves to the person, according to the location in which he is going to place it. Such a boiling-tank may be erected all complete at the present time ( $I$ QI8), including an inexpensive cover, under $£ 30$. It of course must be understood that if this boiler is out of doors an indoor place must be provided for the women to peel the material. A further inexpensive method where the boiling facilities are of a more extensive character, is to purchase half of an ordinary steam boiler cut longitudinally, bricked in and flued as in either of the cases mentioned under the heading "Boiling," with soot-cleaning doors fixed on each side, so that a constant clear draught can always be assured. But buffing in the most satisfactory way can only be done by fixing the boiler in a building which is large enough for the peelers to stand on each side and peel the rods directly from the hot water. To attempt to peel rods when in a cold condition adds greatly to the labour and splits the rods in consequence of the peeling being performed with breaks. Further, it fails to give that good buff colour which is so essential for high-class productions. 


\section{Peeling Buff}

The boiling process not only gives the rods a pleasing colour, but also prepares the skin for peeling, which is ustually done by women or boys. The skin may be removed by the hand alone or with the help of breaks.

(a) By the hand alone.-The peelers stand on either side of the tank and strip the rods whilst they are still hot. They commence by gently forcing the skin back from the butt end for an inch or more, so that it forms a kind of rosette around the rod. The rod is then reversed, the skin pressed by the fingers and thumb, and the rod pulled by the butt end with the other hand. The skin is left in the one hand, and the rod comes away clear, free from all bark, and quite unbruised in any way. This process of peeling certainly leaves the rods in an excellent condition.

(b) By the aid of breaks.-(I) Some growers of exclusively small material use a forked hand-break, made either of a hard wood or iron, something like a tuning fork. The peeler, holding about six rods in her hand, uses the break to release the bark at the butt ends and to force it back as before to form rosettes around the rods. The rosettes of skin are then gripped with the left hand and the rods drawn through with the other hand. This process entirely strips the rods of their skin, and several are drawn at a time.

(2) When the rods have been graded before boiling, so that they are of even size, a more expeditious method may be employed. Two pieces of wood, the bottom fixed, and the top hinged at the end of the bottom one and worked by a spring suspended from above, are used to form a break. Both pieces of wood are fitted with a strip of india-rubber about 15 in. long by $\frac{1}{2}$ in. square. 
The work is difficult and can only be well done by two strong workers, one of whom takes from eight to twelve rods in his left hand and with his right rubs the butt ends together until he forces the peel for 8 in. back into a rosette or knot; these peeled butt ends are laid inside the wooden jaws, the top wood is brought down and pressed on to the rods by means of the foot on a cord. The second man grips the butt ends of the rod and pulls them through the break.

The skins are left behind and fall to the ground. The india-rubber has a soft action on the rods and there is no splitting or bruising.

This system gives the quickest results, but saves little in cost owing to the high wages demanded by the men who do this laborious work.

(3) In the West of England the rods are stripped by the use of the fixed breaks in the same way as for "white " rod. The practice is less suited to boiled rods, as they get bruised and split, and their value is greatly reduced.

The rate paid for peeling buff by hand in 1918 was usually $6 d$. to $8 \frac{1}{2} d$. per bundle, according to the size of the crop, in a green state. ${ }^{1}$ The "bundle" is 36 in. in girth, as measured with a strap about a foot from the butt end as the rods lie on the rack behind the peelers.

The peeled rods are afterwards drafted into different lengths, any rough or badly grown rods being thrown out in preparing high-class material. In this work a wooden standard is used, on which are marked the different lengths: it is fixed on the inside of a tub sunk two-thirds' into the ground. The first drafts, being the longest, are called No. I, and vary from

1 If the rods are buffed dry, the price is increased. 
$6 \mathrm{ft} .6$ in. down to about $5 \mathrm{ft} .6$ in. ; then follow No. 2 , $5 \mathrm{ft} .6 \mathrm{in}$. to $4 \mathrm{ft} .6$ in. ; No. $3,4 \mathrm{ft} .6 \mathrm{in}$. to $3 \mathrm{ft} .6 \mathrm{in.} \mathrm{;}$ - No. $4,3 \mathrm{ft}$. 6 in. to $3 \mathrm{ft}$; and if any smaller are left (Nos. 5 and 6) they are usually put together.

\section{Drying for Buff}

After the skins have been stripped off, the rods are placed on end in the open air, resting against a support of galvanised wire fencing or rails so as to dry out the bulk of the water through exposure to the sun and air (Fig. 7). If ordinary wire is used it soon becomes rusty. This is calculated to leave an impression on the rod, which for high-class material must be avoided. As the drying continues, colouring develops. The depth of colour produced varies with the variety of willow used, the length of time of boiling, the length of time of exposure and the light and sun conditions. All the rods should, therefore, be exposed so as to get a uniform shade of colour. This drying process needs skill and experience to produce good results, and the process should be under the supervision of a skilled worker. When the correct colour shade of buff has been obtained, the rods are taken into the drying-rooms and laid on wooden racks, supported on rests from the floor to the ceiling. This room should be fitted with a drying-fan, as, without the aid of artificial drying, it is almost impossible to buff on an extensive scale in winter-time. Buffed willows are peculiarly subject to mildew, and, if stacked away in a damp condition, will soon turn mouldy and become spotted.

Even when the rods are dried by heat, the bunching of buff should not be hurried during the winter months, since the atmosphere has a powerful effect on buff 


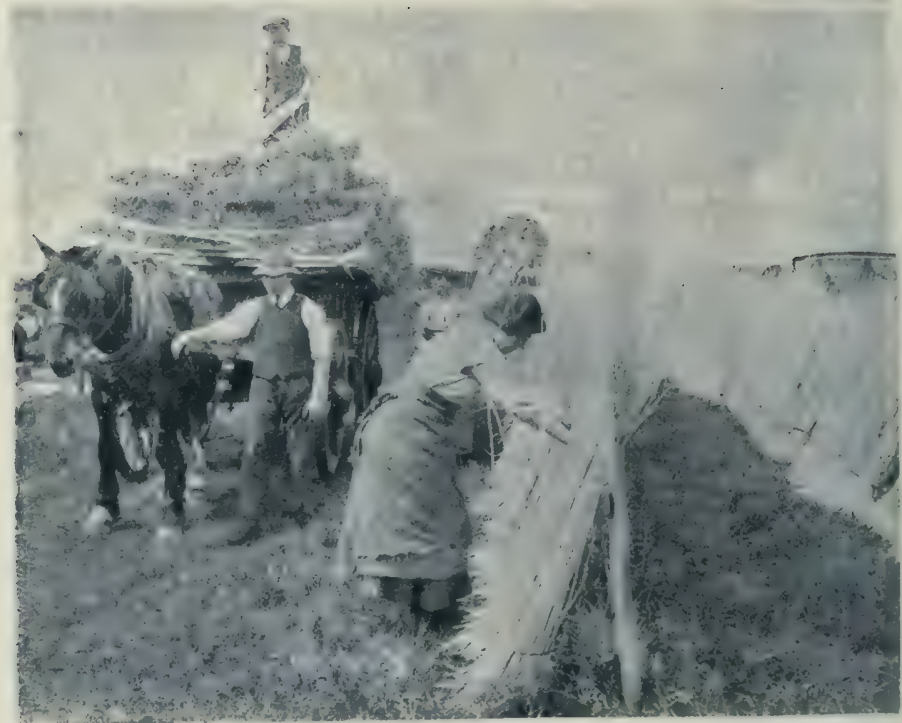

Fig. 7. - White Rods out to DRy.

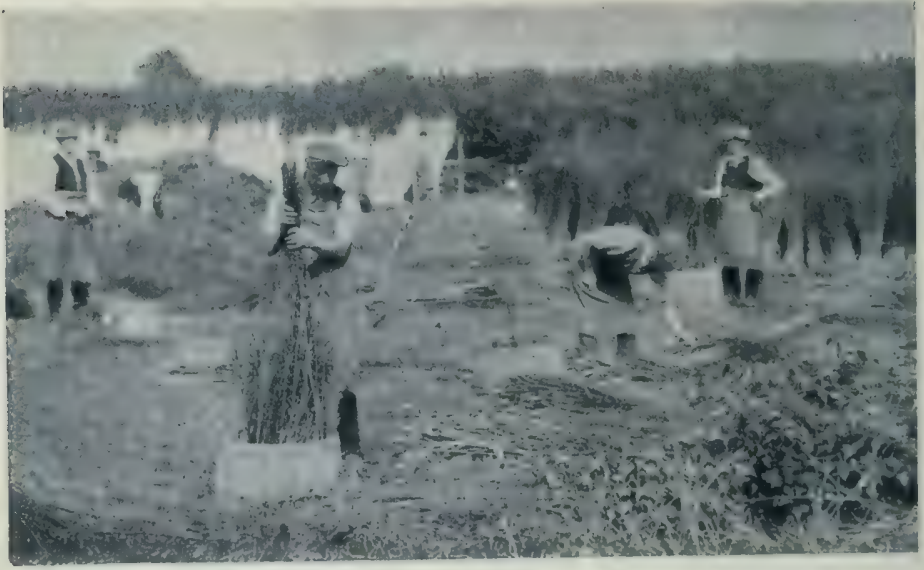

Fig. 8.-Grading Willows into Different Lengths.

To face page 69. 


\section{PREPARATION AND MARKETING}

rods, and, if bunched tightly for export, they may be greatly damaged during a journey of any considerable length.

\section{Grading and Tying into Bundles}

Grading.-Good rods always find a ready market, and the difficulty of selling increases with the poorness in quality. It frequently suits a grower to clear all his stock annually, so as to save labour, to avoid storing and waste, and to make room for the next crop. In such cases grading is purposely not practised. In former years grading was, perhaps, not so necessary, as the basket-maker made many kinds of goods and could thus use up all kinds of rods. The industry has, however, now become so specialised that a maker can find little or no use for rods which are unsuitable for making his one special class of goods. The price offered for ungraded rods and mixed willows is low, because of the expense of sorting out the material required, the packing, and the necessity for reselling those rods which are unsuitable. In view of the higher price obtainable, the grower would be well advised to grade his rods. Grading according to length is not sufficient. Quality and evenness in colour must also be taken into account (Fig. 8).

Tying.-The bundles should also be neatly tied. If the rods are placed upright in the bundles and secured with two, or, in the case of long rods, three, bands tied neatly, the bundles present a pleasing appearance and realise better prices.

It is known that the rods imported from Belgium and Germany were far inferior in quality to the homegrown rods, but found a readier market because they were graded in a satisfactory manner, neatly bundled and tied. On the other hand, the rods from France, 
though far superior to these in quality, caused much dissatisfaction amongst merchants because of the careless grading as to quality, several varieties frequently being found in one bundle.

\section{Brown, and How to Preserve it.}

The rods which have been neither "buffed " nor " whitened " are known as brown-being sold with their skins on. This class of material under normal conditions of labour generally consists of rods of inferior growth or quality, and, consequently, the price is low.

If the whole crop is to be sold as brown, cutting may be done after the rods have ripened, which is soon after all the foliage has fallen. Any time after this, and before the sap begins to flow, would be a suitable time. The cut willows are tied into bundles and spread out in heaps of six bundles deep in long rows, with the butt ends pointing all towards the south, where under the drying action of the wind and sun the rods become cured and turn brown. To prevent the willows heating in the heaps, it may be necessary to turn the bundles two or three times. When dry, the rods must be tied into bundles securely, taking care that the loop end of the band is strong, because it is the loop that represents the strength of the band; the bundles should be shaken level at the butt end and tied firmly with at least two bands. If the crop is free from weeds the bundles, without curing, may be stacked in the open much in the same manner as a farmer stacks his hay. The roof after being built up as an ordinary haystack, should be thatched with the roughest bundles of the crop. Start by placing a row of bundles side by side, sufficiently up from the eaves so that the tips will 


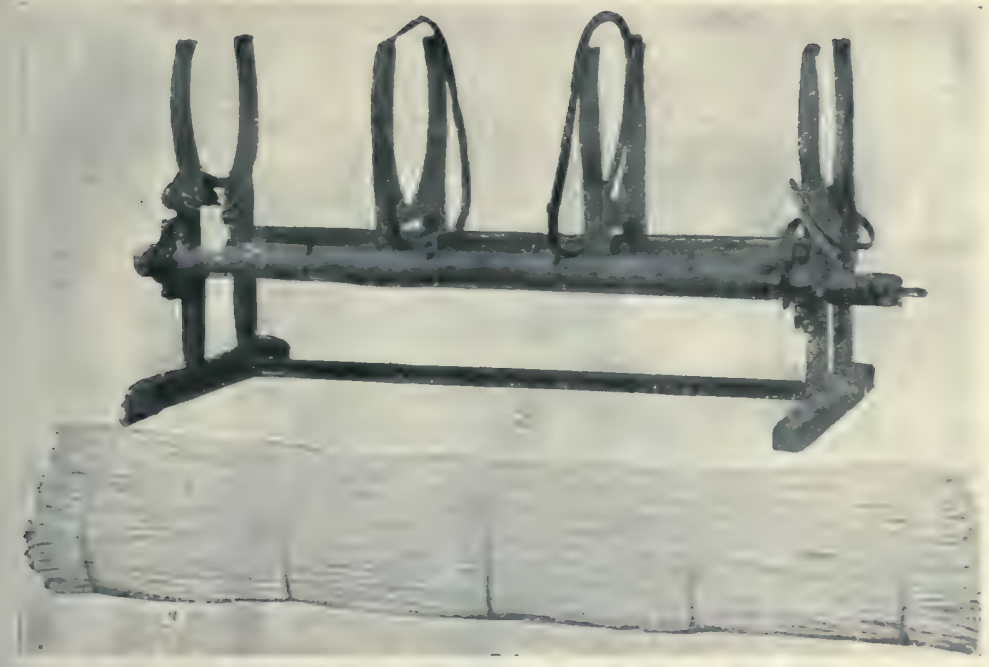

Fig. 9.-MACHINE FOR TYING WILlow RODS FOR'EXPORT.

It enables the bundles to be tied of equal size at each end, and also in the middle. $a$ shows the style of tying adapted for export, with all tops protected.

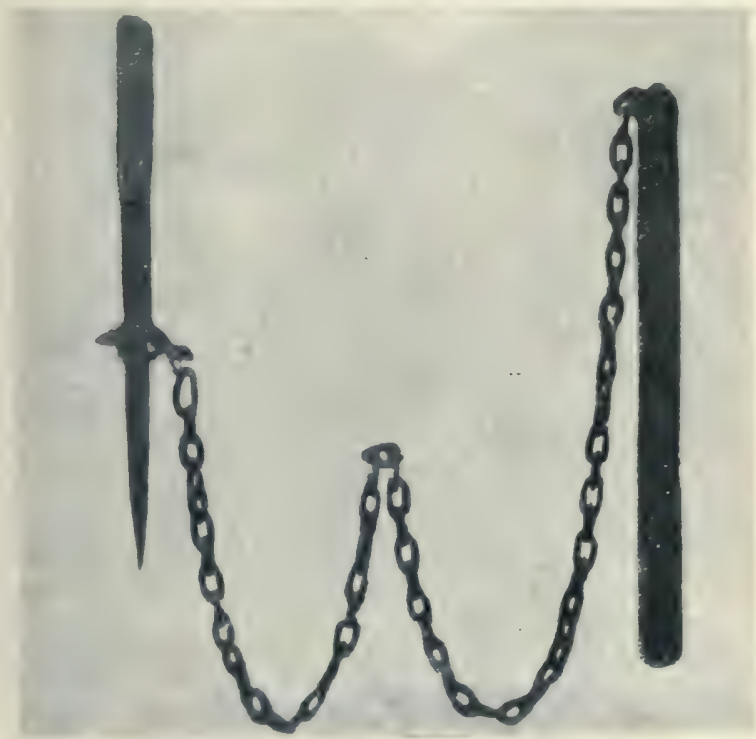

Fig. 10.-Stefl Peg Axd Chain for Tightening the Bunde BEFORE PUTTING ON THE WILLOW BAND. 

overhang the sides about $2 \mathrm{ft}$. Then place the next row higher up the top, the butts being in a line with the ridges and the tips overlapping the butts of the first series. Repeat this on the opposite side with longer stuff, so that the top series of bundles have an overlap of about 18 in. over the butts on the other side which come level with the ridge. Secure these bundles with ordinary thatch pegs into the body of the stack. In this condition the willows will keep sound and saleable for several years, so that a grower may await the best market. Large quantities of brown are accumulated by some growers, much ultimately being wasted, whilst others manage to dispose of all their "brown" each year.

It may be gathered, therefore, that only rods of the same variety and of approximately the same size and length should be included in the bundles. The rods should stand upright in the bundles and be secured by willow bands tied in a careful manner.

The fact that the size of the bundle varies with each district makes trading difficult, and selling by weight is now becoming more popular and should be adopted by all. Leicestershire now has no standard size or weight of bundles, but sells exclusively by the hundredweight, including the bands. Nottinghamshire growers tie in " half-bunches," weighing $35 \mathrm{lb}$. of rods. A pound extra is allowed per half-bunch for the two bands, which are breeched. All growers in that county, as well as in the adjoining parts of Lincolnshire, quote at the present time a price per bunch of five stone of $\mathrm{I}_{4} \mathrm{lb}$. Those districts prepare and sort only into two sizes, called hullings and rods.

In Huntingdonshire and Cambridge they are sorted into sizes known as Small, Threepenny, Middleboro', 
and Great. These are tied by the aid of a special machine in bolts of 40 in. in girth, measured 8 in. for the smaller sizes, Io in. for the Threepenny and Middleboro', and $I 2$ in. for the Great, up the bolt from the butt. Rods are afterwards " pricked in" round the band so as to fill up every crevice. The grower quotes his price per load of 80 bolts, the average weight of a load being about one and a half tons (see Figs. 9-12).

The tying machine (Fig. 9 (2)) was made especially for export tying, and is the only one known in this country. It enables a bundle to be tied of equal size at each end and also in the middle. This was found to be necessary because shippers would only carry rods by the measurement ton. The bundle (Fig. 9 (2a)) shows the style of tying adapted for export. It protects all the tops from injury. The steel peg and chain (Fig. ro) will be found a very efficient tool for tightening the bundle before putting on the willow band. Fig. II is a very simple and efficient machine suitable for growers who are not expert tiers.

Somerset growers tie up in bundles of 38 in. at 3 in. above the butts, and here again (with few exceptions) always quote a price per bolt. Berkshire growers, who usually produce a good class of large stuff, grade their willows into Tack, Short Small, Long Small, Threepenny, Middleboro' and Great, tie their bolts 40 in. in girth at Io in. above the butts, and quote by the load. In Huntingdon, Cambridge, Eastern Counties and Berkshire the actual growers frequently decline to do business unless the buyer will take the entire crop. This plan is very inconvenient, for it often happens that a buyer who has contracted to take the entire produce finds himself overdone with a size of material not well adapted for his particular class of work, and the makers 



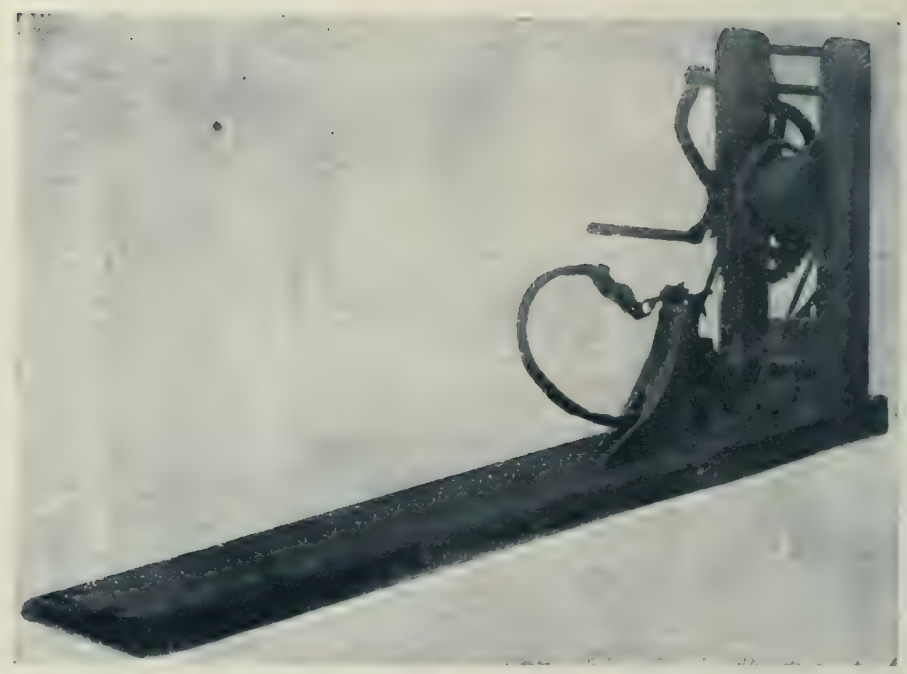

Fig. I1.-MAchine for Tying Willow Rods.

A very simple and efficient machine suitable for growers who are not expert tyers.

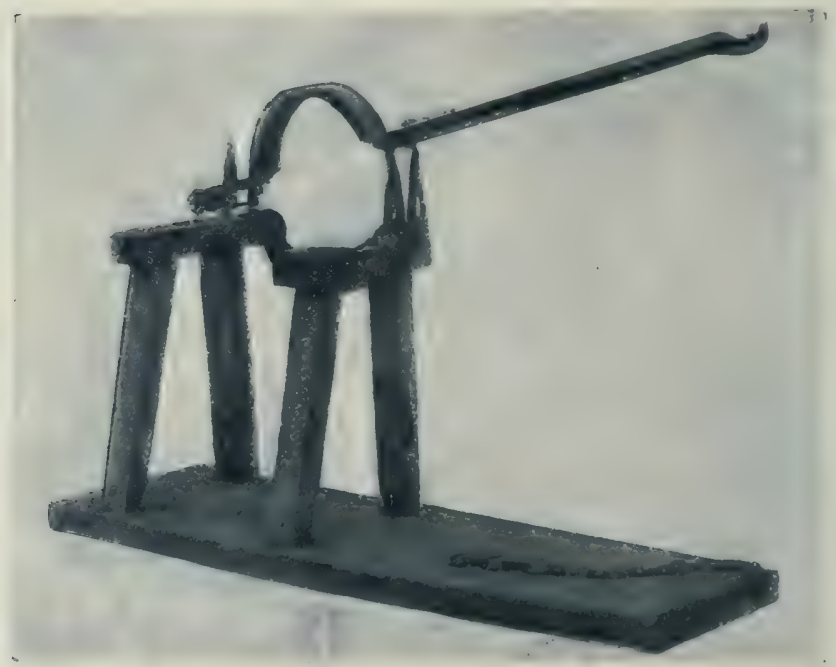

Fig. I2. - Machine For tYing Willow Rods into Bundies. The rods are "pricked in" round the band, so as to fill up every crevice. To face page 72 . 
of special goods are forced to purchase from rod merchants. The profits of these middlemen might just as well be obtained by the growers.

There are no established markets for willows in this country. In the West of England auction sales are held annually, when fields are sold at prices which have realised up to $f I 9$ IOs. per acre in the autumn of I9I7, the purchaser to cut and harvest the crop. The average over a considerable area worked out at about $£$ I8. Also here and elsewhere the buying is in the hands of merchants and manufacturers, who regularly visit the willow-growing centres towards the end of the growing period to judge the value of the crop when standing and to purchase any dry material which the growers may have in stock. Frequently sales are effected by the forwarding of samples. Sewage-farm grown willows are often advertised for sale by tender.

If, as is invariably the case, some part of every crop - especially the outside portion of the bed-is inferior or rough, it will be found best to lay such material on one side for brown, or, if peeled, tie it up by itself and sell according to its value.

The export business, at one time of considerable value, has been much neglected in this country. The growers in Leicestershire and Nottinghamshire, whose crops twenty years ago were frequently shipped as white, have for years sold their crops as green before Christmas for buffing. Consequently very limited quantities have been available for export. This trade has been absorbed by the Belgians, Dutch, Germans, and French. The export business has since the war largely recovered itself, and if attention is given to the proper grading of qualities, there is every prospect of the trade being retained. 


\section{CHAPTER V}

\section{INSECT PESTS OF BASKET WILLOWS}

FEW plants are more subject to the attacks of insects than willows or osiers, and in any season the crop may be so damaged as to be almost worthless. The fungus diseases, on the other hand, are not so numerous. It is only possible to deal here with a few of these pests, most of which will already be familiar to growers, though in many cases they have no wellknown English names. They may, as a rule, be recognised by the type of injury they cause, and it may, therefore, be convenient in the first place to describe certain characteristic attacks to enable the grower to recognise the pest by which his crop is damaged. The types of injury are divided into (I) those which affect the leaves, the top or terminal bud or shoot of the rod; (II) those which affect the rod itself; (III) those which affect the stump.

The following table is intended to assist the grower in recognising the pests by which his beds are attacked.

\section{I.-Damage to Leaves and Terminal Buds}

(a) Leaves and shoots eaten by dark green or blue beetles (which fall but do not jump when disturbed) or by their larvæ, which are blackish or yellowish grubs, sometimes known as Army Worms. See also 
II (a) below. Common Willow Beetles (Phyllodecta vitelline and $P$. vulgatissima).

(b) Similar damage, but light brown beetles present. Galerucella Beetle (Galerucella lincola).

(c) Leaves eaten by livid blue and orange caterpillars. Willow Sawfly (Nematus salicis).

(d) Leaves with yellow or red lumps on them. Willow Gall Sawlies, Pontania salicis, and others.

(c) Leaves and young shoots covered with black or green fly or "blight," or with sticky honey dew, or with honey dew and black mould. Willow Aphides (various species).

(f) Terminal or end bud of shoot tied up with a few fine strands of silk and often containing a brown chrysalis or a small caterpillar which feeds on the young growing leaves. See also $I I(a)$ below. Small Willow Moths (various species).

(g) Terminal or end bud in the form of small rosette or button, often known as " button top." Gall Midges (Cecidomyia heterobia and C. rosaria, etc).

(h) Leaves covered, especially on the underside, with orange-yellow spots. Spots brown later in the season. Willow Rust, caused by the fungus Melampsora.

\section{II.-Damage to Rods.}

(a) Rods with lateral or branch shoots near the top, usually shorter than normal rods, often known as "bushy topped." This injury is usually the result of the destruction of the terminal bud when the rod is growing. Willow Beetles, Willow Moths, Aphides, and, perhaps, Gall Midges.

(b) Rod covered with black fly or blight, the 
insects closely crowded together and often killing the rod. Willow Aphides (especially Melanoxantherium salicis).

(c) Young rod in early summer broken. as if by wind, but close examination shows a hole or puncture at the point where the break occurred. Willow Weevil (Cryptorrhynchus lapathi).

(d) Rods, especially of two years' growth, with minute pin-holes through the bark near the base. Inside are small burrows often containing minute orange red (or green?) grubs. Willow Wood Midge (Cecidomyia saliciperda).

(e) Rods, mainly when of two or more years' growth, with a channel bored up the centre near the base, sometimes containing a white grub or a beetle. Willow Weevil or Willow Clearwing Moths.

(f) Cankerous wounds on the rod. Developing mostly in winter. Wounds not preceded by elongated orange yellow pustules. Willow Canker, caused by the fungus Botryospharia gregaria.

(g) Cankerous wounds on the younger portion of the rods. Always preceded by elongated orange yellow pustules which are found in summer. Rust Canker, due to wounds formed by the rust fungus Melampsora.

\section{III.-Damage to Stumps}

Stumps with burrows and channels, often dying and containing white grubs, chrysalides, or beetles. Willow Weevil, Musk Beetle, Willow Clearwing Moths.

The following sections deal in greater detail with the insects and fungi themselves. - 


\section{Insect Pests}

Willow Aphides.-There are several species of aphides which attack willows, and, on the whole, they are, perhaps, the most serious pest with which the grower has to contend. By sucking the juices of the plants, they stunt and kill both leaves and rods. They also secrete large quantities of honey dew which falls on the leaves, coating them over with a kind of varnish, and greatly accentuating the damage done by the insects themselves. Further, a black fungus or " mould," commonly grows on the honey dew, coating the leaves still further, and making it impossible for them to carry out their functions. It should be emphasised that the honey dew is always the product of the aphides, and is not a separate form of blight due to climatic conditions, an opinion which is commonly held but which is quite erroneous.

It is unnecessary here to enter into the features by which the various species are distinguished, and, in many cases, their habits require further investigation. It may, however, be mentioned that certain common species (Siphocoryne caprea and S. pastinacece) live partly on the willow and partly on weeds such as hemlock, wild parsnip, chervil, angelica, etc. (Umbellifer $e$ ), and special attention should, therefore, be paid to the eradication of such weeds.

Species of Aphis common on the leaves and shoots are Aphis saliceti, the two species above mentioned, and Pterocoma pilosa. The most common species on the rod itself is Melanoxantherium salicis.

Willow Beetles (Phyllodecta vitellina, $P$. vulgatissima). -In the adult state these insects are shining dark green or blue beetles. They first appear in spring 
and early summer and at once attack the developing shoots and leaves, causing great injury by eating into the growing point of the rod. Eggs are laid in groups on the underside of the leaves, and in a short time produce small dirty grey or yellow coloured grubs or larvæ, which at first remain together eating away the underside of the leaf. Later, as they grow larger, they spread to other leaves, devouring each so that only the upper paper-like cuticle is left, and, in severe cases, all the leaves on the plants are killed. When full fed, the larvæ fall to the earth and change into pupæ from which beetles are produced. There are two broods of beetles in the season, but the generations overlap somewhat, so that beetles and larvæ are often found together. The beetles of the second brood leave the rods in autumn and crawl into heaps of rubbish, under the bark, and into the crevices in pollard willows, and shelter there during the winter, reappearing to attack the willows again the following spring.

Beetles of the genus Phyllodecta are common all over the country, and all willow-growing areas are subject to their attacks. They are perhaps especially harmful in the Midland and East Anglian districts.

Galerucella Beetle (Galerucella lineola).-This insect in the adult state is a yellow brown beetle with dark markings on the upper surface. In its life-history and habits, with the exception of certain minor differences, it resembles the Phyllodecta beetles just described. It appears, however, to spend the winter in damper places, and is specially harmful in the Somerset district.

Willow Weevil (Cryptorrhynchus lapathi). - This beetle, on account of its long trunk or proboscis is sometimes known as the elephant beetle. It is partly 
blackish-brown in colour and partly yellow (or pink when freshly emerged).

The adult beetle appears from early summer onwards, and may be found clinging to the rod with its trunk buried in the soft growing portion, which subsequently bends over as if broken by the wind. At the smallest disturbance the beetle falls to the ground and remains motionless, looking very like a bird dropping. Eggs are laid in the stumps or rods (?) and produce white, grub-like larvæ which burrow in the stumps and sometimes up into rods of two years' growth. Cryptorrhynchus larvæ have no legs, which distinguishes them from the larvæ of the clearwing moths, and they are round and somewhat short, and so differ from the - larvæ of the Musk Beetle, which are rather long and flat. When full fed they pupate in the burrows and the beetles emerge from the pupæ in the autumn, but seem to remain in the burrow until the following spring.

Cryptorrhynchus lapathi attacks alder as well as willow, and is common in all willow-growing areas, notably in Somerset. It is a serious pest, for in addition to the annual destruction of a large number of rods by the adult, the larva does great injury to the stumps.

Musk Beetle (Aromia moschata). - This insect is a large, shining blue or green beetle with long antennæ. When disturbed it gives out a strong musky smell. The larva is a large white grub, legless, and rather long and flat in shape. It feeds in pollard willow trees and in old willow stumps, especially when these are grown with a "long leg." It can hardly be regarded as a serious pest when willows are well grown, but is worthy of mention as it is so large and conspicuous that it is apt to excite interest. 
Willow Sawfly (Nematus salicis).-Reference is made to this insect as it causes much loss on the Continent and occasionally does so in this country. The larva is a livid blue and orange caterpillar which feeds on the willow leaves and may completely defoliate the rods. It can hardly be confused with any other pest. Recently notes of serious damage have only been received from the Peterborough district, and information in the event of further attacks would be welcomed.

Willow Gall Sawflies (Pontania gallicola).-There are also other species of sawfly besides $N$. salicis which may be expected at times to do damage. Enquiry is often made as to the cause of the red and green globular or bean-shaped swellings which are so common on the leaves of willows. The insects responsible are certain species of gall sawfly, of which that mentioned above is most common. The sawfly larva lives in the gall, and when full fed burrows out and pupates in the soil. Unless the galls are so numerous as to weigh down the rods, the injury does not seem to be serious.

Willow Moths.-The larvæ of many different moths feed on willow, but with certain exceptions they are seldom present in sufficient numbers to do serious harm. The exceptions comprise (I) various species of small moth, the larvæ of which feed in spring and summer in the terminal shoot of the rod; (2) certain clearwing moths whose larvæ burrow in the stumps and in the rods.

(I) Further investigation is required before the lifehistory of each species can be described in detail. The larvæ first become noticeable in late spring when they spin together a few leaves at the tips of the growing rods, forming small tubes or nests, one larva only being found in each shoot. They feed on the growing 
buds and leaves, and when full fed change into brown chrysalides in the nests, from which in due course the moths emerge. The damage is serious, since it prevents the rod from attaining its full length and also, owing to the destruction of the growing point, encourages the production of lateral shoots, a condition known as "bushy top." So far as the Somerset district is concerned the most common species are Hypermacia cruciana and Depressaria conterminella.

(2) There are two species of willow clearwing moth, of which the first, Trochilium bembeciforme, the Willow Hornet Clearwing, so closely resembles a large wasp or hornet that it may readily be passed over. The second species, the Red Tipped Clearwing (Sesia fonicaforme) also has little resemblance to a moth, and is perhaps more like an ichneumon fly. The larvæ of these moths are white, grub-like caterpillars with brown heads and eight pairs of legs, which are small but evident. The Hornet Clearwing larva lives inside the stumps and especially in rods of two years' growth or more. The larva of the Red Tipped Clearwing lives mainly on the stumps. The larvæ of both species pupate in the spring in the burrows, and the moths emerge in June and July. The damage done by these insects is not very evident unless a few stumps are cut open, when it is often found that the wood is tunnelled in all directions by the larvæ, which at first reduce the productiveness of the stump and later kill it altogether. These two species and the Willow Weevil (Cryptorrhynchus lapathi) are the insects chiefly responsible for the decay of stumps.

Willow Gall Midges.-These insects in the adult stage are minute midges or flies. The most injurious species lay eggs in the terminal buds of the rods, which 
subsequently fail to develop normally and become bunched together or form a distinct rosette. These galls are usually known as buttons or button tops. In the galls are found one or more minute orange-red larvæ, which, when full fed, either pupate in the galls or fall out and pupate in the soil. There appear to be two generations in the year, and it is believed that the winter is spent as a larva in the galls, but statements on these points do not always agree.

The most injurious species is known as Cecidormyia heterobia, and may be recognised by the fact that the buttons contain many larvæ and are rather shapeless, not as a rule in the form of a neat rosette. A second species, Cecidormyia rosaria, produces galls which may be distinguished by the fact that they each contain only one larva and are rosette-shaped.

The injury done by these insects is decidedly serious, since attacked rods are stunted and may also be " bushy topped.".

There are several other species of gall midge which attack willows, but mention need only be made of the willow wood midge, Cecidormyia saliciperda. The larvæ of this insect live in burrows in the rods, usually near the base. They pupate in the burrows and the flies emerge, through minute pin-holes in the bark. The winter is spent in the larval condition in the rods.

Attacked rods which are more often of two years' growth are of little value, as the attacked portion is weak and must be cut away.

Methods of Control.-No suggestions as to practical methods of control have been given in the preceding sections since the few forms of treatment known may be applied in the case of attack by several kinds of pest. Notes under this heading may be divided into 
(I) direct measures which may be adopted when an attack is expected or is actually in progress; (2) indirect measures which will tend to reduce the numbers of the various pests in the beds and so prevent further attacks.

(I) Direct Measures.-As a matter of general principle, when the foliage of any plant is being eaten by beetles or caterpillars, the first measure to be considered is some form of poisonous spray which will leave a coating of poison on the leaves and so kill the insects as they feed. The poison most commonly used for this purpose is lead arsenate, but it should be noted that in the case of the basket willows grown in this country, spraying with lead arsenate has proved a complete failure, probably on account of the fact that the leaves have such a smooth surface that the poison cannot stick on. If this explanation is correct, the difficulty should be easily overcome; but until a formula has been proved successful by experiment, it is suggested that in the case of all attacks by leafeating beetles, caterpillars, or grubs, a wash containing nicotine and soap should be used. . Insecticides of this nature have been found efficient in practice, and their application is treated below in connection with aphides.

When plants are attacked by aphides or other insects which feed by sucking up the juices of the plant and not by eating the solid parts, it is necessary to use a contact insecticide, that is to say, an insecticide which kills those insects which are touched by it. There are several such washes, but the only one which seems to have been properly tested on willows is nicotine, which is undoubtedly the best contact insecticide known. It has also the additional advantage of 
being quite efficient when used against leaf-eating insects, such as willow beetles. The great drawback to it is its expense, but this is, at least in part, balanced by the number of different pests which it can destroy. It is now widely used in the Somerset district, and some growers are so satisfied with the results that they spray regularly with it as a preventive, even though no insects are at the moment doing any injury. When used in this way it must be looked on as a form of insurance.

The following details of the costs of spraying were obtained from the Somerset growers who usually use a proprietary nicotine and soap mixture :-

Amount of spray fluid used per acre, 40-60 gallons.

Cost of spray fluid per gallon, $I d$. to $\mathrm{I}_{5} d$.

i.e. 5 gallons cost $5 d$. to $6 d$.

Cost of spray fluid for I acre, $3 s .4 d$. to $6 s$.

Cost of labour per acre (piece-work), 2s. $6 d$.

Amount which one man can spray in one day using knapsack sprayer, I acre to 2 acres.

Messrs. Bradford's figures :-

40 gallons of water.

I $\frac{1}{2}$ lb. Nico-soap at 2s. per I lb.

i.e. 3s. per acrie.

Man spray 2 acres a day on piece-work at 2s. $6 d$. per acre. i. e. cost $5 s .6 d$. per acre.

It is probable that the cost of nico-soap has risen beyond the original price of $f I$ per ro lb.

Messrs. Bradford estimate the cost of material as slightly less than that given above, but these details are, of course, only approximate, since, in the first place, the amount of fluid used will vary in accordance with the size of the rods; and secondly, the price of nicotine is liable to fluctuation.

The percentage of nicotine in these proprietary 
insecticides cannot be stated, but those who wish to make up their own wash with a known nicotine content might try the following formula, varying it from time to time to find the minimum percentage of nicotine which is effective :-

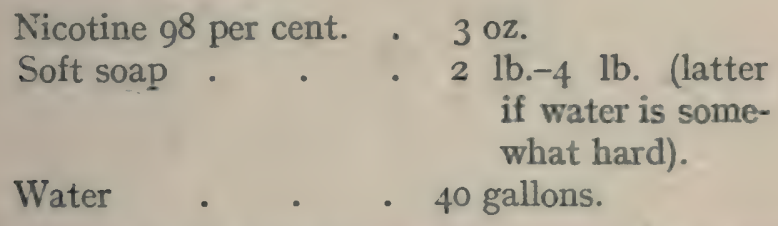

The number of times which it is necessary to spray is also variable; sometimes as many as three applications are made as a regular routine, but it is probable that if the willows are well sprayed in late May or early June it will seldom be necessary to spray again the same year.

Apart from spraying which will deal with aphides, leaf-eating grubs and beetles, and to a less extent with the moth caterpillars which live in the shoots, no other direct measures for control can be recommended for actual experience. On the Continent the leaf-eating willow beetles are caught by various forms of apparatus by means of which the insects are shaken off into trays, and some such method might be of service in this country in the case of the Willow Weevil (Cryptorrhynchus lapathi), against which sprays are useless. No control measures are known in the case of the midges causing button top or in those of the various insects which burrow in the stumps or rods. In button top, however, assuming that the insects pass the winter in the buttons, and remembering that affected rods are usually of little value, it seems regrettable that such rods should be left about in the neighbourhood 
of the beds until the late spring, when the midges will emerge and attack the new crop.

(2) Indirect Measures.-In addition to the direct measures of control which can be applied to the growing crop there are certain precautionary measures which are worth consideration as they would tend to prevent the necessity for spraying. It has been pointed out that willow beetles spend the winter in heaps of rubbish, under bark, etc. It is, therefore, obvious that all such heaps left until the spring are a source of danger, while equally, if they are burnt during the winter, they will have acted as traps, and allowed the easy destruction of many pests. In the same way it is probably a mistake to allow old pollarded willows-however picturesque-to remain close to willow beds. They are always thoroughly infested by willow-feeding insects of all kinds, and must act as centres from which these insects spread to the neighbouring beds. If willow trees are needed they should be of a variety which will pay for proper attention, and they should not be pollarded. Neglected and decayed willows, poplars or alders are all undesirable in the neighbourhood of willow beds.

Willow stumps which are partly dead or weak are usually attacked by the insects which burrow inside, such as the larvæ of Cryptorrhynchus lapathi and of the clearwing moths. Such stumps should be removed and burnt as soon as the rods are cut. If they are left, the insects will emerge and attack fresh stumps, and the bed will gradually become unproductive. 


\section{CHAPTER VI}

\section{TREE WILLOWS}

THERE are in Great Britain only two species, known in the trade as White and Red Willow, that produce commercial timber, but of each there are several varieties and local forms. The wood of the White Willow is always more or less tinged with red, but the Red variety is decidedly redder than the White and finer and closer in its grain, and the timber is heavier per cubic foot; but as my object is not to go into small botanical details, but to confine myself mainly to the practical features, reference will be made only to those for which there is a large commercial outlet.

The species are-

(I) The Salix fragilis, or White Willow, known also as the Crack Willow, easily distinguished by its open or coarse bark, with deep corrugations and with a deeply serrated leaf double the size of the Red Willow.

(2) The Salix rubra, or Red Willow, is easily distinguished from the White by its finer, closer and much shallower corrugations on the bark, and by its smaller and very finely serrated leaves.

Both these willows may be seen growing in every part of the British Isles, mostly as pollarded trees, which destroys their commercial value, excepting for fencing poles or bobbin turners.

The Salix carulea, or Blue Willow, also known as the Cricket Bat Willow, or Close Bark Willow, is an 
intermediate variety between the ordinary red and white species and is clearly distinguished by the blue tone of the foliage, whence its name is derived. Its habit of growth is marked by an upright or pyramidal character, not spreading out to anything like the same angle as the two species previously named. In all other respects as to size of foliage and serrations it is very similar to the ordinary Red Willow.

This variety of the Red Willow has found the greatest favour and realised the most fancy prices. Its main branches (see illustration) grow at angles of 30 to 45 degrees. At the Agricultural Show held at Nottingham in I9I5, when I exhibited specimens of the Cærulea variety growing in tubs, several manufacturers of high-class cricket bats assured me that they had paid in isolated instances as much as $£ I 00$ for a single tree; whilst the prevailing prices at that period (I9I4-I5) for the best grown Cærulea reached I4s. per cubic foot, and ordinary qualities of the Red Willow realised 5s. to Ios. per cubic foot-prices sufficient to justify an extended cultivation. It will be found to do best in a rich loam with heavy subsoil.

The so-called Huntingdon Willow is a variety of the ordinary White Willow, and up to a comparatively few years since was regarded as an ideal kind for cricket-bat making. The Red Willow is also largely grown in the Huntingdon and adjoining districts. A colleague of mine planted in the Leicester district a White Huntingdon Willow in rich alluvial soil. "-At eight years old it had grown to a height of $35 \mathrm{ft}$., and its circumference at I ft. from the ground was 33 in. Another of the same variety, planted on gravelly soil, reached $24 \mathrm{ft}$. in height, and at a foot from the ground measured 23 in. in circumference; a third planted in 


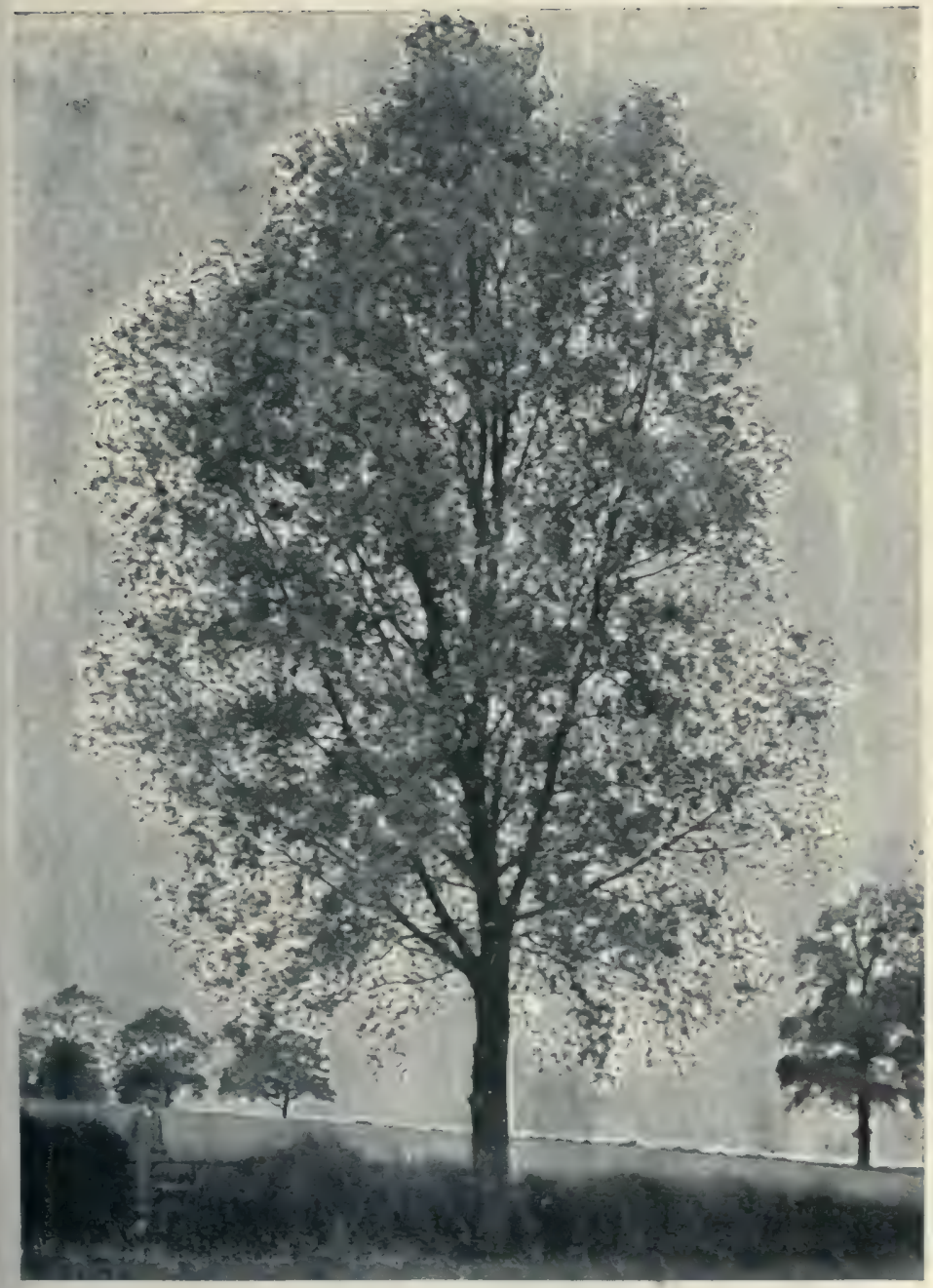

Fig. 13.-A Willow TreE. 

a peaty soil, with a subsoil of clay, only attained $26 \mathrm{ft}$. in height and had a girth of 24 in. at a foot from the ground. These experiments show the class of soil on which this willow gives the best results.

On page 1520 of Loudon's Arboretum Britannicum reference is made to a cutting planted by Mr. Brown of Hetherset, Norfolk, that in ten years became a tree of $3.5 \mathrm{ft}$. in height, with a girth of $5 \mathrm{ft}$. The same publication cites a twenty years' tree at Audley End, Essex, which reached $53 \mathrm{ft}$. in height and $7 \mathrm{ft} .6$ in. in girth.

In the Kew Bulletin of Miscellaneous Information No. 8, I907 (p. 3II, No. L.), in an article by W. J. Bean, Esq., on the Cricket Bat Willow, it is stated that "No question in connection with profitable treeplanting has roused greater interest in recent years than that as to the kind of willow best adapted for the manufacture of cricket bats. It has only attained importance in recent times because it is only lately that the supplies of the best bat willow have become seriously limited, and that prices have risen in proportion. At a sale of willows of Sir Walter Gilbey's at Sawbridgeworth in February, I906, the best bat willow realised prices estimated to be equivalent to 75 . per cubic foot. I have recently been informed by the agent of a large estate in Essex that he had declined an offer of $£$ I 500 for Ioo of the best willow trees on the estate, and Mr. John Shaw, of the well-known firm of Shaw \& Shrewsbury, Nottingham, last winter offered $£ 40$ for a tree. When it is known that trees have been known in favourable situations to reach a saleable size in twelve years (having in that period attained a girth of 50 in.) these prices show that there is no timber so profitable at the present time as that 
of the cricket-bat willow. It is not surprising, therefore, that owners of land suitable should have been attracted by this tree. As a matter of fact a large number of trees have been planted during the last few years with a view to meeting the future demands, but we have it on the authority of Mr. Shaw-one of the largest buyers as well as a leading expert-that not more than one-fourth of the trees that are being planted are the best cricket-bat willow."

The increasing demand for willow timber for the making of artificial limbs has practically denuded the country of supplies suitable for this purpose. I have received applications from French, Belgian and South African Government Departments, asking if this material is procurable in England. Unfortunately, in spite of many inquiries $I$ have been unsuccessful in finding much of the right quality. Makers of artificial limbs for the Allied Forces have been compelled to seek their supplies from America, where merchants have done a large and profitable business in a variety known in the U.S.A. as Salix nigra-Marsh, a variety which is not common in this country. It is recorded by the U.S. Department of Agriculture, Bulletin No. $3 \mathrm{I} 6$, that this variety grows to $4 \mathrm{ft}$. in diameter, $5 \mathrm{ft}$. from the ground, and I40 ft. in height. The bark of this particular variety is very corky, in some instances being $I \frac{1}{2}$ in. to 2 in. thick. The leaves are 3 in. to 6 in. long, a bright green, and rather shiny. The timber appears, from its clean-cleaving qualities, to be related to our English White Willow.

The wood of the willow is light, smooth, soft and extremely tough. It will bear more hard knocks without splinter or injury than any other wood, and has no rival for making cricket bats. There is nothing 
to equal it for floats for paddle steamers or the strouds of water-wheels, and it wears longer in water than any other wood. It provides the best brakes for railway coal-wagons and luggage trucks; it is the only wood that will stand that kind of pressure and concussion without fracture. Its extreme elasticity and toughness make it the best of woods for the sides and bottoms of carts and barrows when work such as loading coal or stone is required, and, were it obtainable in sufficient quantities, it would be the best material for constructing passenger carriages forr our railways; since carriages made of this wood would be less liable to be splintered by collision. The wood of the willow, like its kindred timber, the poplar, burns slowly and is not easily kindled, a quality which ought to be a considerable recommendation where it is necessary to use wood in close proximity to fire. Years ago willow was very largely used by powder manufacturers for charcoal, and was preferred to any other wood. It is still so employed in the U.S.A., and its discontinuance has only come about owing to the short supplies. The wood of the willow is much esteemed by painters for their crayons, and for domestic uses nothing is so suitable for making wooden bowls, Lancashire clogs, yokes for milkers, milk buckets, moulds for buttons, cutting-boards for all classes of trades requiring boards; basket-makers greatly appreciate it for sieve rims, seed-hoppers and scuttles.

In the remote event of any extensive planting of the best willow trees, an acre, if planted $3 \mathrm{ft}$. apart with trees of two years' growth, would require 4840 . This would not be too close for the first eight or nine years, when they might be thinned out to half that number. The thinnings would find a ready sale for 
general farm purposes. At about sixteen years they might be further reduced to I2Io trees-or $6 \mathrm{ft}$. apart each way, which would afford ample space for their further development. There is plenty of evidence to show that it is not an uncommon thing for a thirtyyear willow tree to yield $45 \mathrm{ft}$. of measurable timberor at the rate of $\mathrm{I} \frac{1}{2}$ cubic $\mathrm{ft}$. per annum. Not, however, calculating on such great results, I will further assume that IIo trees out of the I2IO are worthless (a much greater margin than would be probable) and that in forty years only one-third of the above quantity, or say half a foot instead of $\mathrm{I} \frac{1}{2} \mathrm{ft}$. per annum, is produced; we shall then have Iroo trees containing an average of 20 cubic $\mathrm{ft}$. each, or $22,000 \mathrm{ft}$. worth, at the lowest computation, 2s. per ft., or $£ 2200$, as the produce of an acre, apart from the two thinnings out, which would be more than sufficient to cover the cost of labour.

The tree willow is one of the easiest to propagate, and the following will be found a very inexpensive and profitable way of securing a stock. Rooted trees of two or three years' growth, if planted $4 \mathrm{ft}$. apart each way, will demand 2722 to the acre. They should be thinned out when six or seven years old to $12 \mathrm{ft}$. apart by taking out the two centre ones. When they are about twelve years old the trees may be further reduced to 300 to the acre, and at about twenty years, or a little more, providing the soil and conditions are favourable, they should be in perfect condition and of a saleable size. The thinnings out in this, as in the previous estimate, should recoup the cost by the sale of the poles. Or, for planting at a small cost, cuttings may be employed and inserted in the ground in the same manner as ordinary basket willow cuttings. 
The first growth must all be cut off, because the shoots, being short and spriggy, are useless for good trees. Open up the soil and add some farmyard manure to stimulate the growth. The following season the shoots will reach from $4 \mathrm{ft}$. to $6 \mathrm{ft}$. in length, or grow even longer. Cut away all shoots excepting the straightest and cleanest and leave the one single shoot. At twenty years, with favourable conditions, the growth should be sufficient to cut four bat lengths.

Pollarding trees destroys their value as timber. The produce of a pollard tree can only be used for fencing purposes. Moreover, it harbours obnoxious insects, fungi, etc., and the wet gets in and deteriorates the interior of the wood.

With all cuttings and trees that I supply, I give a guarantee that they are the best cricket-bat strain of the Cærulea. The stock was originally obtained from Kew Gardens, and is certified by the authorities as the true variety. At the time of writing-December, Igr8-I have an unusually well-grown stock of two- and three-year-old rooted plants which I am prepared to offer at exceedingly reasonable prices.

Cuttings from two-year-old wood, I2 in. to $I_{4}$ in. long, IOs. per I00.

Two-year-old rooted trees, $4 \mathrm{ft}$. to $6 \mathrm{ft}$. long, 35s. per Ioo.

Three-year-old rooted trees, $6 \mathrm{ft}$. to $8 \mathrm{ft}$. long, $50 s$. per Ioo.

If the trees are selected and pruned, ro per cent. extra. Net cash, carriage forward, packing charges extra. 
The period for planting in the British Isles is from November to the early part of April.

My willow grounds and nursery contain over seventy different varieties set out in beds of each kind and can be seen by appointment by those interested in the business. 


\section{CHAPTER VII}

\section{IMPORTS AND EXPORTS}

IN the Midlands and the North of England the cost of labour has risen so considerably that many acres of willows have passed out of cultivation. Added to this, there has been a depression in the local basketmaking trade, and the small men, who are generally also growers, have considerably curtailed their industry and allowed many of their willow holts to die out. Large basket-making firms have increased their areas. The following figures from the Board of Trade returns, however, show that the home supply of rods is quite insufficient for the basket-making industry :-

VAlue of the Total Imports of WIILOWS aNd CaNes for BASKET-MAKTNG.-FREE OF .DUTY. ${ }^{1}$

\begin{tabular}{|c|c|c|c|c|c|}
\hline From & Igro. & IgII. & I9I2. & 1913. & I9I4. \\
\hline $\begin{array}{l}\text { Germany } \\
\text { Netherlands : } \\
\text { Java } \\
\text { Other Dutch Possessions } \\
\text { Belgium } \\
\text { Other Foreign Countries }\end{array}$ & $\begin{array}{l}\frac{f}{4} \\
30,366 \\
9,702 \\
3,005 \\
8,177 \\
7,925 \\
6,509\end{array}$ & $\begin{array}{r}t \\
33,698 \\
14,791 \\
7,058 \\
7,292 \\
11,160 \\
7,538\end{array}$ & $\begin{array}{l}t \\
38,2 \text { II } \\
14,109 \\
4,9 \text { II } \\
1,754 \\
12,614 \\
6,851\end{array}$ & $\begin{array}{c}t \\
34,246 \\
19,569 \\
10,477 \\
7,896 \\
12,288 \\
9,798\end{array}$ & $\begin{array}{r}t \\
26,983 \\
25,773 \\
12,269 \\
7,297 \\
8,416 \\
10,896\end{array}$ \\
\hline $\begin{array}{l}\text { Total, Foreign Countries } \\
\text { Straits Settlements and } \\
\text { Dependencies, including }\end{array}$ & 65,684 & 81,527 & $7^{8,450}$ & 94,274 & 91,634 \\
\hline $\begin{array}{l}\text { Labuan } \\
\text { Other British Possessions }\end{array}$ & $\begin{array}{r}14,360 \\
5,842 \\
\end{array}$ & $\begin{array}{r}2 I, 09 I \\
3,678 \\
\end{array}$ & $\begin{array}{r}\mathrm{I} 7,747 \\
\mathrm{I}, 5 \mathrm{I} 4 \\
\end{array}$ & $\begin{array}{r}28,852 \\
347 \\
\end{array}$ & $\begin{array}{r}33,349 \\
496\end{array}$ \\
\hline Total . & 85,886 & I06, 296 & 97,7 II & I 23,473 & I 25,479 \\
\hline
\end{tabular}

1 It should be noted that the materials imported from the tropics for basket-making are canes and not willows, but it is probable that they might be replaced by willows in many forms of basket-ware. 
Value of the Total Imports of Baskets and Basket-Ware FREE OF DUTY,

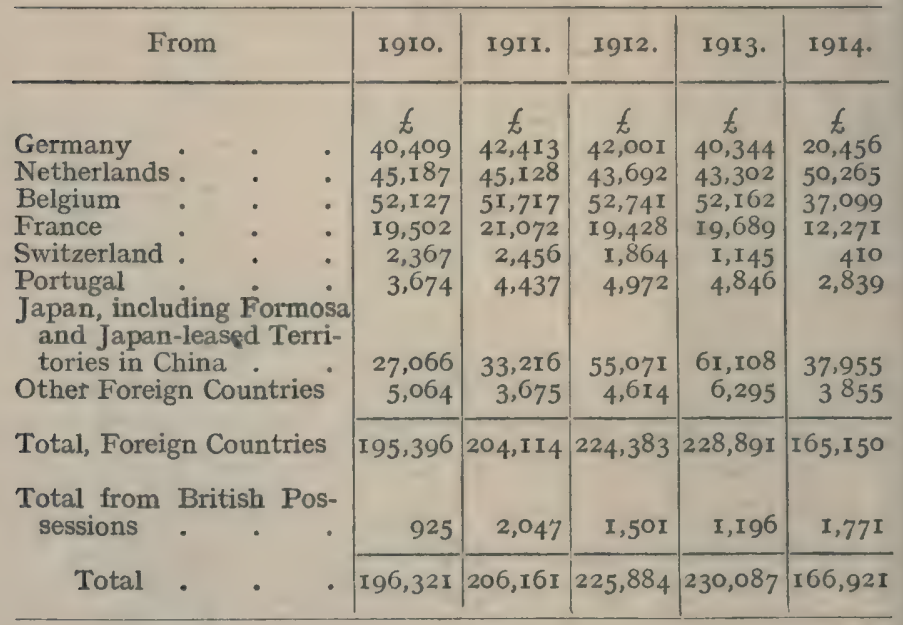





